\title{
Acceptability and feasibility of introducing the WHO focused antenatal care package in Ghana
}

\author{
Harriet Birungi \\ Population Council \\ Philomena Nyarko \\ Population Council \\ Margaret Armar-Klemesu \\ Daniel Arhinful
}

Sylvia Deganus

See next page for additional authors

Follow this and additional works at: https://knowledgecommons.popcouncil.org/departments_sbsr-rh

Part of the Demography, Population, and Ecology Commons, International Public Health Commons, Maternal and Child Health Commons, and the Women's Health Commons How does access to this work benefit you? Let us know!

\section{Recommended Citation}

Birungi, Harriet, Philomena Nyarko, Margaret Armar-Klemesu, Daniel Arhinful, Sylvia Deganus, Henrietta Odoi-Agyarko, and Gladys Brew. 2006. "Acceptability and feasibility of introducing the WHO focused antenatal care package in Ghana," FRONTIERS Final Report. Washington, DC: Population Council. 


\section{Authors}

Harriet Birungi, Philomena Nyarko, Margaret Armar-Klemesu, Daniel Arhinful, Sylvia Deganus, Henrietta Odoi-Agyarko, and Gladys Brew 


\section{Acceptability and Feasibility of Introducing the WHO Focused Antenatal Care Package in Ghana}

Frontiers in Reproductive Health Program, Population Council Philomena Nyarko Harriet Birungi

Noguchi Memorial Institute for Medical Research Margaret Armar-Klemesu

Daniel Arhinful

Tema General Hospital, Ghana Health Service

Sylvia Deganus

Reproductive and Child Health Unit, Ghana Health Service

Henrietta Odoi-Agyarko

Gladys Brew

June 2006

This study was funded by the United States Agency for International Development (USAID) under the terms of Cooperative Agreement Number HRN-A-00-98-00012-00 and Population Council Sub-agreement No.AI04.50A. The opinions expressed herein are those of the authors and do not necessarily reflect the views of USAID. 


\section{Table of Contents}

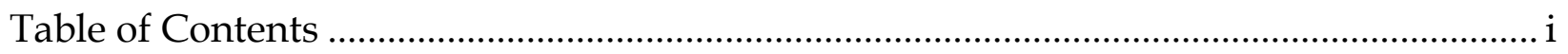

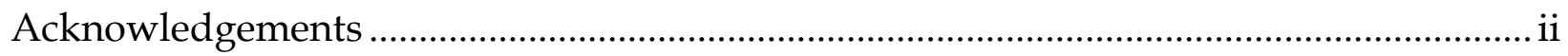

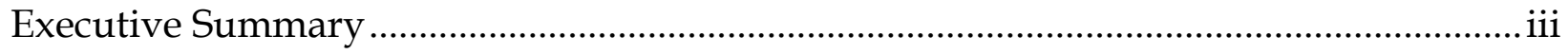

List of Acronyms ............................................................................................................iv

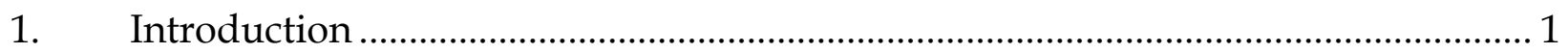

1.1 The context for introducing focused ANC in Ghana ..................................................................

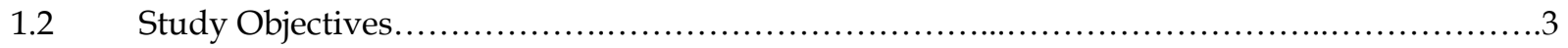

2. Study design and data collection methods .............................................................. 3

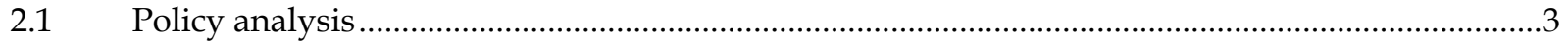

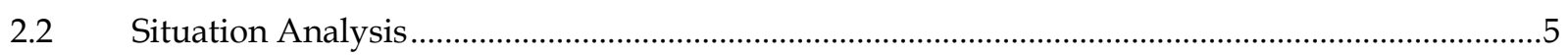

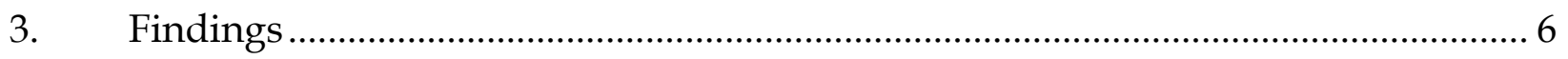

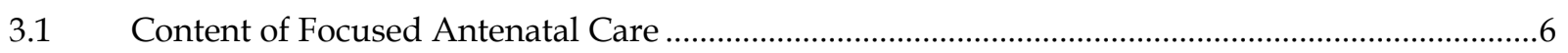

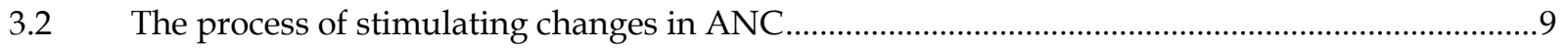

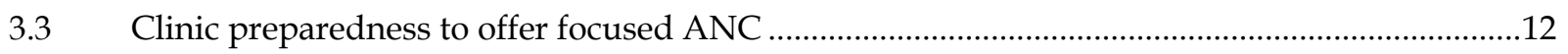

3.4 Awareness of focused ANC package and services ....................................................................13

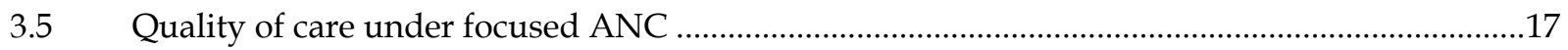

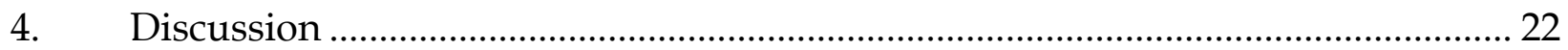

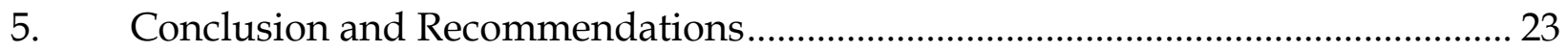

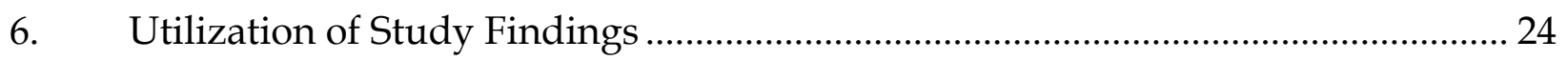

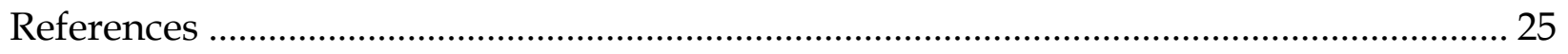

Appendix A: Definition of quality of care indicators ........................................................... 26

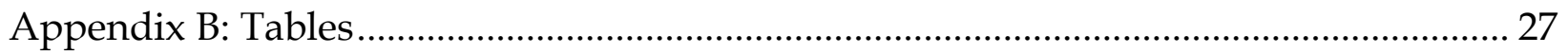




\section{Acknowledgements}

We gratefully acknowledge the invaluable support received from the Director of the Noguchi Memorial Institute for Medical Research, Prof. David Ofori-Adjei, during the planning and implementation of this project. We also wish to acknowledge the substantial contributions made by the staff of the Reproductive and Child Health Unit of the Tema General Hospital towards our understanding of focused antenatal care in Ghana. This knowledge, to a great extent, shaped the design of the study.

We wish to thank the research assistants who worked tirelessly to provide us with the needed data. We also wish to extend our gratitude to the data manager, Mr. Emmanuel Amoquandor, whose kind support made this report a reality.

We would like to acknowledge Dr. Aaron Ofei and Dr. Irene Agyepong Amartefio, Central and Greater Accra Regional Directors of Health Services, for giving us permission and supporting us to undertake the study in the two regions. We are also very grateful to the staff of the Reproductive and Child Health Unit of the Ghana Health Service, the District Health Management Teams of Tema Municipal, Accra Metropolis, Cape Coast Municipal and AburaAsebu-Kwamankese, Mfantsiman, Gomoa, Ewutu-Efutu-Senya and Agona Districts, management of the health service institutions, program managers, providers, clients and all other individuals for their co-operation, participation, and invaluable contribution towards the study.

Our appreciation also goes to Dr. Ian Askew, Dr. John Townsend and Ms. Joanne Gleason of Frontiers in Reproductive Health Program, Population Council, for their critical review of the draft report. We would also like to thank Dr. Ayo Ajayi, Ms. Barbara Jones and Dr. Placide Tapsoba of the Population Council, Ghana, Pradeep Goel, Mrs. Juliana Pwamang and Mr. Emmanuel Essandoh of USAID, Ghana, Dr. Johnny Gyapong of the Health Research Unit of the Ghana Health Service, Dr. Gifty Addico of the UNFPA, Dr. Nicholas Kanlisi, Ms. Joyce Ablordeppey and Dr. Richard Killian of Quality Health Partners and all others not mentioned here for their constructive comments during the presentation of the study findings.

Finally, we would like to thank Ms. Isabella Rockson and Ms. Angela Gadzekpo of the Population Council, Ghana, for their administrative support throughout the entire study period. 


\section{Executive Summary}

The Government of Ghana has adopted the WHO focused antenatal care (ANC) package in a move to improve access, quality and continuity of ANC services to pregnant women. As part of these efforts, the Government has exempted fees for ANC clients. The main objective of this study, undertaken by Noguchi Memorial Institute for Medical Research in collaboration with the Ghana Health Service (GHS), FRONTIERS, and with USAID funding, was to examine the extent to which adaptation of the package influenced quality of care received by pregnant women and its acceptability to both providers and clients. The study used a policy analysis and a situation analysis in ten intervention clinics in which the package had been introduced and four comparison clinics. Data were collected through key informant interviews, focused group discussions, client exit interviews, client card reviews, observations of provider-client interactions and review of facility records.

The results indicate that national-level support for focused ANC is high. The package appears to have been well accepted by both clients and providers because of its comprehensiveness and the individualized care. Some components of the package were lacking in several clinics, in particular procedures for disease detection (e.g., testing for syphilis and HIV/AIDS). Existing opportunities for referral were also not fully utilized. Client awareness of the content of focused ANC was poor and usually confused with the free delivery policy, underscoring the lack of community sensitization about the new package. Clients appreciated the individualized care and privacy during service delivery and birth planning. There was no significant difference in the timing of ANC visits by clients accessing care from intervention and comparison clinics. Staff competence was influenced by attrition and poor targeting of staff for in-service training. The need for additional physical infrastructure was also a challenge as most clinics partition their existing consulting rooms. Essential drugs, supplies and equipment were also lacking in a number of the facilities.

Refocusing ANC has resulted in significantly better quality of care, notably in prevention of diseases (e.g., malaria and anaemia in pregnancy), promotion of health (e.g., counselling on STI/HIV/AIDS) and continuity of care. Clients visiting the intervention clinics obtained more comprehensive care than those visiting the comparison clinics. However, introduction of focused ANC had no effect on comprehensive history taking, birth planning and complication readiness, and postpartum care.

The process of stimulating changes in focused ANC service delivery will need further consultation of key stakeholders (e.g., pre-service training institutions and professional bodies) to ensure its institutionalization. Community-level education is also required to create awareness about the timing of ANC visits, individual birth planning, advice on danger signs and self-care in pregnancy, complication preparedness and the need to involve other family members in birth planning. 


\section{List of Acronyms}

$\begin{array}{ll}\text { ANC } & \text { Antenatal Care } \\ \text { DHMT } & \text { District Health Management Team } \\ \text { EU } & \text { European Union } \\ \text { FANC } & \text { Focused Antenatal Care } \\ \text { FGD } & \text { Focus Group Discussions } \\ \text { GDHS } & \text { Ghana Demographic and Health Survey } \\ \text { GHS } & \text { Ghana Health Service } \\ \text { GOG } & \text { Government of Ghana } \\ \text { GSPA } & \text { Ghana Service Provision Assessment } \\ \text { HIV/AIDS } & \text { Human Immuno-deficiency Virus/Acquired Immune Deficiency Syndrome } \\ \text { IBP } & \text { Individual Birth Planning } \\ \text { IPT } & \text { Intermittent Presumptive Treatment of malaria in pregnancy } \\ \text { MOH } & \text { Ministry of Health } \\ \text { NGO } & \text { Non-Governmental Organization } \\ \text { PMTCT } & \text { Prevention of Mother-to-Child Transmission } \\ \text { PNC } & \text { Postnatal Care } \\ \text { RH } & \text { Reproductive Health } \\ \text { RCH } & \text { Reproductive and Child Health } \\ \text { RTI } & \text { Reproductive Tract Infections } \\ \text { SDP } & \text { Service Delivery Point } \\ \text { SP } & \text { Sulphurdoxine Pyrimethamine } \\ \text { STI } & \text { Sexually Transmitted Infections } \\ \text { TT } & \text { Tetanus Toxoid } \\ \text { UNFPA } & \text { United Nations Population Fund } \\ \text { UNICEF } & \text { United Nations Children and Education Fund } \\ \text { USAID } & \text { United States Agency for International Development } \\ \text { VCT } & \text { Voluntary Counseling and Testing } \\ \text { WHO } & \text { World Health Organization } \\ \end{array}$




\section{Introduction}

\subsection{The context for introducing focused ANC in Ghana}

Complications of pregnancy and childbirth are a major cause of death for women of reproductive age in Ghana. The national maternal mortality rate is estimated at 214 deaths per 100,000 . However, rates vary widely by district and region, with some northern districts having a maternal mortality rate as high as 800 per 100,000 live births (Ghana Health Service, 2002). The major causes of maternal death in Ghana do not differ much from those reported in other Sub-Saharan African countries. The direct causes include sepsis, haemorrhage, and hypertensive disorders of pregnancy, unsafe abortion and complications of obstructed labour. The indirect causes include malaria, anaemia, malnutrition and opportunistic infections associated with HIV/ AIDS1 (UNFPA and MOH, March 2004). A skilled birth attendant (doctors, nurses and midwives) attends less than half (48 percent) of the births in Ghana (GDHS, 2003).

A substantial proportion (45 percent) of pregnant women wait until the second or third trimester to seek ANC, when it is too late to take potential preventive measures for some complications such as anaemia. By the start of the sixth month of pregnancy, 12 percent of Ghanaian women have not made a single ANC visit. The median duration of gestation at which the first ANC visit is made is 4 months. Worse still, an estimated 6 percent of women do not make a single ANC visit; this figure is higher (9 percent) in rural areas (GDHS 2003).

Problems of availability, accessibility, coverage and quality of care limit the potential gains of ANC services. Of the 375 facilities surveyed in the 2002 Ghana Service Provision Assessment (GSPA), 88 percent offered ANC services; of these 78 percent provided ANC services on five or more days a week, and 18 percent offered ANC services once or twice a week.

In addition, most clinics tend to be more specialized, offering ANC and other essential services on separate days. For instance, only 63 percent of the facilities offered both ANC and Tetanus Toxoid (TT) vaccination on the same day. Provision of family planning as a routine component of ANC was offered at 62 percent of the facilities, malaria prophylaxis was a routine component at 71 percent, and anaemia and urine testing for protein was routinely included at 70 percent of the facilities. Diagnosis and treatment for clients with STI symptoms without referring the client elsewhere was a routine component of ANC in just 44 percent of the facilities. Most hospitals offered a specialized service, with only 18 percent including STI management in ANC. Voluntary Counseling and Testing (VCT) for HIV / AIDS and syphilis screening are clearly not yet a routine component of ANC in Ghana, with only 8 percent and 4 percent of facilities respectively including VCT and syphilis screening during ANC. Quality of care was poor, as described in the box below. The 2003 sentinel survey among women attending ANC clinics shows HIV prevalence range of 0.6 - 9.2 percent (Ghana Health Service, March 2003) and the HIV prevalence rate among all women in the reproductive age group is estimated to be 2.7 percent (GDHS, 2003). 
Thus, even when pregnant women made ANC visits they were likely to receive poor quality services that were not comprehensive. Moreover, the "assembly line" approach to delivery of ANC services, whereby clients can see up to six different providers for various services and spend approximately six hours per visit, does not encourage proper monitoring or follow-up and/ or continuity of care (personal communications:

Obstetrician and Gynaecologist, Tema General Hospital and Head, Reproductive and Child Health Unit, GHS). The assembly line approach is also perceived as impersonal because a woman does not have an individual provider with whom to share her experiences (Personal communication: Staff of Quality Health Partners Project). Educational talks are given regardless of clients' information needs, and privacy of individual clients during consultation was rarely ensured.

The $\mathrm{MOH}$ has exempted fees for four visits per women attending ANC. This initiative, which also includes free delivery care, was first introduced in the four poorest regions of Ghana (Northern, Upper West, Upper East and the Central regions) between October and November 2003 (RCH Annual Report, 2003) and was extended to the other regions of Ghana in 2004 (RCH Annual Report, 2004). The WHO focused ANC package (Villar et al 2001), which encourages four ANC visits and individualized care, was also adopted in 2002. This package seeks to promote the health and survival of mothers and babies, through:

\section{Quality of Care during ANC}

1. Only 6 percent of facilities offering ANC services had all the essential medicines to manage complications of pregnancies (i.e., antibiotic for infections, deworming medicine, an anti-malarial, and at least one medication for treating trichomoniasis, gonorrhoea, chlamydia and syphilis).

2. Tests for anaemia and protein were only available in 57 percent and 62 percent of the facilities, respectively.

3. Only half of the facilities had all essential equipment and supplies for ANC, including a blood pressure apparatus, fetoscope, iron and folic acid tablets and TT.

4. Only 36 percent of facilities had essential items to offer quality counseling, 24 percent had essential items to prevent infections and 11 percent had all essential items for quality physical examination.

5. Routine history taking from clients was not comprehensive - some first visit clients were not asked about their age, date of last menstrual period, any prior pregnancy, and medicines being taken.

6. Identification of signs and symptoms of risk was inadequate - only 29 percent of clients were asked about vaginal bleeding, 53 percent of women who were at least 5 months pregnant were asked about foetal movement and only 22 percent of clients were subjected to all relevant components of pregnancy monitoring.

7. Tetanus toxoid was given or prescribed to 51 percent of first visit clients and to 34 percent of follow-up clients, while anti-malarials were given to 47 percent and 34 percent of first-visit and follow-up clients, respectively. Preventive screening for syphilis was done for less than 5 percent of the ANC clients.

8. Clients were not properly counseled to promote healthy outcomes - among women attending ANC for the first time, only 20 percent were counseled about exclusive breast feeding. Discussion of the progress of the pregnancy and delivery plans was observed in one-third of interactions. Risk symptoms - vaginal bleeding, fever, breathlessness, swelling of hands and face, headache, or blurred vision - were discussed with only 27 percent of the clients. Use of family planning postpartum was observed in only 19 percent of interactions.

Source: 2002 Ghana Service Provision Assessment 
- Targeted assessments of pregnant women to ensure a normal child bearing cycle and newborn period, and to facilitate the early detection of complications, chronic conditions, and other potential problems that could affect the pregnancy; and

- Individualized care to help maintain the normal progress of pregnancies, including preventive measures, supportive care, health messages and counseling of women and families for effective self care, and birth preparedness and planning for complications.

For women whose pregnancies are progressing normally, WHO recommends four ANC visits, ideally at less than 16 weeks, at 26 weeks, 32 weeks and 36 weeks (http://www.who.int/reproductive-health/publications/RHR_01_30/). Each visit should have care that is appropriate to the overall condition and stage of pregnancy and should include:

- Identification of pre-existing health conditions,

- Early detection of complications arising during pregnancy,

- Health promotion and disease prevention, and

- Birth preparedness and complication planning.

\subsection{Study objectives}

The major concern in Ghana is whether the health care system can cope with implementation of the focused ANC package. Moreover, acceptability of the package among service providers and clients, as well as the process and feasibility of introducing it at different service delivery points, is currently unknown.

The overall objective of the study was to assess the GHS's capacity to adapt focused ANC at the service delivery level and examine the extent to which adaptation of the package has increased coverage and quality of key ANC services and overall quality of care received by pregnant women. Specifically, the study addressed the following key questions:

1. What contextual and process issues are influencing the feasibility and acceptability of the focused ANC package?

2. Is focused ANC acceptable to clients and providers?

3. What is the actual content and coverage of focused ANC and are all components being provided as a package at the service delivery level?

4. What effect does focused ANC have on the quality of care offered to pregnant women?

\section{Study design and data collection methods}

The study used an integrated case study design, involving policy and situation analyses. The assessment was conducted at the national level and in two regions: Greater Accra, where some of the first initiatives for focused ANC were introduced, and Central region.

\subsection{Policy analysis}

The conceptual model developed by Walt and Gilson (1994) for analyzing health policy development and program implementation was applied retrospectively. Their model identifies and examines factors that have affected, or will affect, implementation of a new or revised policy/programme and circumstances that have influenced its outcome. The model takes into 
account the programme content, the actors involved, the processes contingent on developing and implementing change, as well as the context within which changes are introduced. Data were gathered through a desk appraisal, stakeholder appraisal and focused group discussions.

Desk appraisal: A desk review of the current National Reproductive Health Service Policy and Standards was undertaken to determine the content and the extent to which they facilitate or influence the provision of focused ANC at the service delivery levels. District health plans, annual and quarterly reports were also reviewed for their intentions to translate policy into actual activities for focused ANC.

Stakeholder appraisal: Key informant interviews were held with 20 major reproductive health actors at the national, regional and district levels (Table 1). Key issues explored through the key interviews centred on contextual issues, actors and content.

\begin{tabular}{|c|c|}
\hline Governmental Organization & $\begin{array}{ll}\text { - } & \text { Reproductive and Child Health Unit (GHS) } \\
\text { - } & \text { Policy Planning, Monitoring and Evaluation Unit (GHS) } \\
\text { - } & \text { School of Nursing } \\
\text { - Midwifery Training School }\end{array}$ \\
\hline $\begin{array}{l}\text { Private organizations, } \\
\text { Professional Associations \& } \\
\text { NGOs }\end{array}$ & $\begin{array}{ll}\text { - } & \text { Nurses and Midwives Council of Ghana } \\
\text { - } & \text { Ghana Registered Midwives Association }\end{array}$ \\
\hline Health Development Partners & - USAID, WHO, UNICEF \\
\hline Technical Assistance Agencies & - JPHIEGO, EngenderHealth, Policy Project \\
\hline Regional and District Actors & $\begin{array}{ll}\text { - } & \text { Regional Director of Health Services (Central) } \\
\text { - } & \text { District Director of Nursing Services-Reproductive Health } \\
\text { (Greater Accra and Central) } \\
\text { - } & \text { Regional Training Resource Person } \\
\text { - } & \text { Public Health Nurses in charge of Reproductive Health } \\
& \text { Services at the District Level }\end{array}$ \\
\hline
\end{tabular}

Contextual issues: Issues included the circumstances under which focused ANC was introduced, how seriously the change in ANC service provision was viewed, challenges faced in implementing the new approach, and whether the change is sustainable. The interviews also focused on the availability of resources needed and the proportions of resources coming from government, NGOs, donors and clients, and their security.

Issues about the actors: The influence of different actors on implementation of the focused ANC package, the main instigators of the change and, in particular, the role WHO played in influencing the government to embrace focused ANC as a national strategy were explored.

Issues about the content: In assessing the content of focused ANC at the service delivery level, the interviews ascertained whether focused ANC service provision varied by level of facility. Other issues explored were how the traditional components of ANC (e.g., iron, tetanus toxoid) were handled after focused ANC was introduced, and how emerging issues such as HIV/AIDS and IPT are being addressed within the safe motherhood programme. 
Focus Group Discussions: Focus group discussions (FGDs) were used to gain a detailed understanding of the process of implementing focused ANC, as well as its acceptability and feasibility among providers and clients. There were 9 FGDs, each comprising $6-10$ individuals who had been exposed to focused ANC (Table 2). Service providers were recruited from intervention clinics, while clients were mobilized from the clinics' catchment communities.

\begin{tabular}{|l|l|}
\hline \multicolumn{2}{|l|}{ Table 2: Categorization of Focus Group Discussions } \\
\hline Categories & Groups per region \\
\hline Service providers & $\begin{array}{l}2 \text { groups from hospitals } \\
2 \text { groups from health centres/polyclinics } \\
1 \text { group of private midwives }\end{array}$ \\
\hline ANC clients & $\begin{array}{l}2 \text { groups of women who had given birth in the past year } \\
2 \text { groups of women who are currently pregnant and have attended ANC }\end{array}$ \\
\hline
\end{tabular}

\subsection{Situation Analysis}

The situation analysis measured the coverage, availability, and quality of care, awareness and acceptability of FANC at the clinic level. Initially, the analysis was to cover 14 clinics; 7 intervention clinics from Greater Accra region and 7 matched comparison clinics from Central region where FANC had not yet been introduced. The two regions had been selected in consultation with the Reproductive and Child Health Unit of the Ghana Health Service and the matching of the facilities was based on type and patient load. However, at the time of study implementation it became apparent that some of the comparison clinics in Central region were already offering FANC, while some of those identified in the Greater Accra region were not. Consequently, ten clinics offering FANC in both regions constituted the intervention sites, while the remaining 4 not offering FANC constituted the comparison sites. Data were gathered through a facility assessment, interviews with providers, observation of provider-client interactions, exit interviews and ANC card reviews.

Facility assessment: To determine coverage and availability of focused ANC in terms of infrastructure, equipment and supplies, a systematic inventory was undertaken at the 14 clinics through interviews with the clinic-in-charge.

Provider interviews: Short structured interviews with providers were conducted to obtain information on their training and knowledge of focused ANC and associated standards and guidelines as well as their attitudes and satisfaction with the package. A sample of 58 ANC providers (36 in the intervention clinics and 22 in the comparison clinics) at the hospital level and all providers in each health centre were interviewed.

Structured observations of client-provider interactions: Observers observed a minimum of six client-provider interactions for each of the four recommended visits and recorded all aspects of the quality of the ANC consultation on a standardized checklist. Consequently, a random sample of 341 client-provider interactions were observed; 246 in the intervention clinics and 96 in the comparison clinics. Only women consenting to be in the study and to have their consultations observed were included. 
Client exit interviews: Short exit interviews were held with each consenting client after the consultation had been observed to ascertain their perceptions of quality of care received and content. All 341 clients agreed to the exit interview.

Review of client's maternal health cards: Maternal health cards provided to ANC clients at first registration and which they are expected to carry along during subsequent visits were reviewed at the point of exit to determine timing of the ANC visit and content of services received by clients. A total of 340 ANC client cards were reviewed, including those that had been observed.

Client flow analysis: Upon entering the clinic, each ANC client participating in the study was given a tracking form, which she carried along with her during the clinic visit. All providers she had contact with recorded the time the contact started and ended, and at the end of all consultations she returned the form to a data collector. The form elicited information on the time the client reported to the clinic and the reason for making a particular contact. A total of 341 clients were followed.

\section{Findings}

\subsection{Content of Focused Antenatal Care}

Table 3 highlights some of the changes and added components in antenatal care introduced through the focused package. Unlike previous guidelines ${ }^{2}$ that emphasized the categorization of clients into risk groups based on their previous obstetric history, medical conditions, age, parity, weight and laboratory investigations, focused ANC does away with the risk assessment criteria and considers all pregnant women to be at risk. Focused ANC also encourages early detection and treatment of all complications arising during pregnancy and underscores the need for birth preparedness and complication readiness, and prevention of malaria in pregnancy and mother-to-child transmission of HIV/AIDS.

Previously, pregnant women were expected to make 13 ANC visits during pregnancy, but focused ANC in Ghana does not actually mention how many times a woman should seek antenatal care $^{3}$. However, interviews with program managers and service providers indicate that a healthy pregnant woman should have four comprehensive, personalized antenatal care visits and receive 'focused' services relevant for each visit. The other added value of focused ANC in Ghana is the individualized care that maximizes quality of care and confidentiality. As one respondent puts it:

"Letting one midwife attend to a client throughout her antenatal period...in a secluded area and where her information (records) would be kept confidential"

(Respondent, Quality Health Partners Project)

Antenatal care services are provided between 4 and 6 days a week in the clinics, with the majority (78 percent) being available 5 days a week. Counselling about developing individual birth plans is the only service that is routinely offered at all clinics. Services offered to varying 
degrees include TT vaccination, malaria in pregnancy (IPT), family planning services, STI treatment, voluntary testing for HIV/AIDS and PMTCT (Table 4).

\begin{tabular}{|c|c|c|}
\hline \multicolumn{3}{|c|}{ Table 3: Changes in the content of ANC in Ghana } \\
\hline Content & Traditional ANC & Focused ANC \\
\hline Objectives & 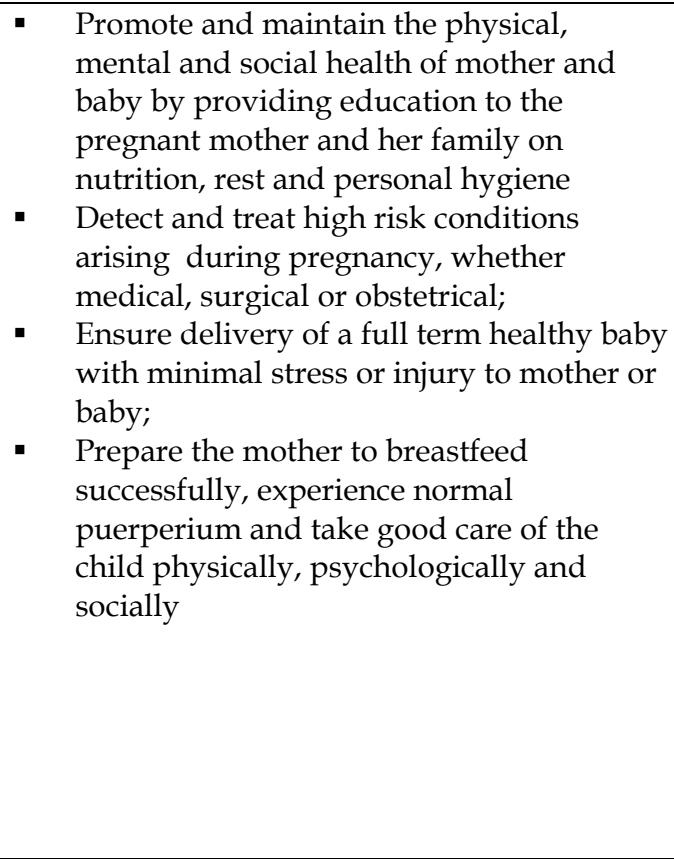 & $\begin{array}{l}\text { - Promote and maintain the physical, } \\
\text { mental and social health of mother and } \\
\text { baby by providing education to the } \\
\text { pregnant mother and her family on } \\
\text { nutrition, rest, personal hygiene, family } \\
\text { planning, immunization, danger signs, } \\
\text { RTI including STI/HIV/AIDS, birth } \\
\text { preparedness and complication } \\
\text { readiness; } \\
\text { Detect and treat complications arising } \\
\text { during pregnancy, whether medical, } \\
\text { surgical or obstetrical; } \\
\text { Ensure delivery of a full term healthy } \\
\text { baby with minimal stress or injury to } \\
\text { mother or baby; } \\
\text { Prepare the mother to breastfeed } \\
\text { successfully, experience normal } \\
\text { puerperium and take good care of the } \\
\text { child physically, psychologically and } \\
\text { socially; and } \\
\text { Prevent mother-to-child transmission of } \\
\text { HIV/ AIDS }\end{array}$ \\
\hline No. of Visits & 13 & 4 \\
\hline Timing of visits & $\begin{array}{ll}\checkmark & \text { Monthly up to } 28 \text { weeks } \\
\checkmark & \text { Fortnightly from } 28^{\text {th }} \text {-36th week } \\
\checkmark & \text { Weekly from } 36^{\text {th }} \text { week to delivery }\end{array}$ & $\begin{array}{ll}\checkmark & \text { 1st visit after two missed periods: }<16 \\
& \text { weeks; } \\
\checkmark & \text { 2nd visit: } 20-24 \text { weeks; } \\
\checkmark & \text { 3rd visit: } 28-32 \text { weeks; } \\
\checkmark & \text { 4th visit: 36 weeks. }\end{array}$ \\
\hline $\begin{array}{l}\text { Comprehensive } \\
\text { medical history }\end{array}$ & $\begin{array}{ll}\checkmark & \text { Personal Medical and Surgical History } \\
\checkmark & \text { Family Medical History } \\
\checkmark & \text { Past Obstetric History } \\
\checkmark & \text { History of present pregnancy } \\
\end{array}$ & $\begin{array}{ll}\checkmark & \text { Personal Medical and Surgical history } \\
\checkmark & \text { Family Medical History } \\
\checkmark & \text { Past Obstetric History } \\
\checkmark & \text { History of present pregnancy } \\
\end{array}$ \\
\hline $\begin{array}{l}\text { General } \\
\text { examination }\end{array}$ & $\begin{array}{ll}\checkmark & \text { Temperature } \\
\checkmark & \text { Pulse } \\
\checkmark & \text { Blood Pressure } \\
\checkmark & \text { Weight and Height } \\
\checkmark & \text { Gait or deformity }\end{array}$ & $\begin{array}{ll}\checkmark & \text { Temperature } \\
\checkmark & \text { Pulse } \\
\checkmark & \text { Blood Pressure } \\
\checkmark & \text { Weight and Height } \\
\checkmark & \text { Gait or deformity }\end{array}$ \\
\hline $\begin{array}{l}\text { Physical } \\
\text { examination }\end{array}$ & $\begin{array}{ll}\checkmark & \text { Hair to toe } \\
\checkmark & \text { Conjunctiva } \\
\checkmark & \text { Nail beds for pallor } \\
\checkmark & \text { Breast and abdomen } \\
\checkmark & \text { Pelvis }\end{array}$ & $\begin{array}{ll}\checkmark & \text { Hair to toe } \\
\checkmark & \text { Conjunctiva } \\
\checkmark & \text { Nail beds for pallor } \\
\checkmark & \text { Breast and abdomen } \\
\checkmark & \text { Pelvis }\end{array}$ \\
\hline $\begin{array}{l}\text { Vaginal } \\
\text { examination }\end{array}$ & $\begin{array}{ll}\checkmark & \text { Confirm pregnancy } \\
\checkmark & \text { Detect position of the uterus } \\
\checkmark & \text { Detect fibromyoma or any extrauterine } \\
& \text { abnormality such as ovarian cyst } \\
\text { Done during first trimester }\end{array}$ & $\begin{array}{l}\checkmark \quad \text { Confirm pregnancy } \\
\text { Done during first trimester }\end{array}$ \\
\hline $\begin{array}{l}\text { Obstetric } \\
\text { examination }\end{array}$ & $\begin{array}{ll}\checkmark & \text { Inspection for scar } \\
\checkmark & \text { Deformities } \\
\checkmark & \text { Palpation for foetal maturity } \\
\checkmark & \text { Auscultation of foetal heart }\end{array}$ & $\begin{array}{ll}\checkmark & \text { Palpation for foetal maturity } \\
\checkmark & \text { Auscultation of foetal heart }\end{array}$ \\
\hline
\end{tabular}




\begin{tabular}{|c|c|c|}
\hline $\begin{array}{l}\text { Laboratory } \\
\text { investigations }\end{array}$ & $\begin{array}{ll}\text { Urine test for: } \\
\checkmark & \text { For proteins (albumin) } \\
\checkmark & \text { Sugar } \\
\checkmark & \text { Midstream specimen of urine for pus cells } \\
\checkmark & \text { Pregnosticon test to confirm pregnancy } \\
& \text { (First trimester) } \\
\checkmark & \text { Test stool for worms } \\
& \\
\text { Test blood for: } \\
\checkmark & \text { Haemoglobin level (Hb) } \\
\checkmark & \text { Full blood count (FBC) } \\
\checkmark & \text { Sickling } \\
\checkmark & \text { Grouping and Rhesus factor } \\
\checkmark & \text { VDRL } \\
\checkmark & \text { HIV (on request) }\end{array}$ & $\begin{array}{ll}\text { Urine test for: } \\
\checkmark & \text { For proteins (albumin) } \\
\checkmark & \text { Sugar } \\
\checkmark & \text { Midstream specimen of urine for pus } \\
& \text { cells } \\
\checkmark & \text { Pregnosticon test to confirm pregnancy } \\
& \text { (First trimester) } \\
\checkmark & \text { Test stool for worms } \\
\text { Test blood for: } \\
\checkmark & \text { Haemoglobin level (Hb) } \\
\checkmark & \text { Full blood count (FBC) } \\
\checkmark & \text { Sickling } \\
\checkmark & \text { Grouping and Rhesus factor } \\
\checkmark & \text { VDRL } \\
\checkmark & \text { VCT }\end{array}$ \\
\hline $\begin{array}{l}\text { Routine } \\
\text { Administration } \\
\text { of Drugs }\end{array}$ & $\begin{array}{ll}\checkmark & \text { Oral iron/folate } \\
\checkmark & \text { Chloroquine tablets weekly for malaria } \\
& \text { prophylaxis; diaprim as back up option } \\
\checkmark & \text { Tetanus toxoid immunization (from } 20 \\
& \text { weeks, with second dose four weeks later) }\end{array}$ & $\begin{array}{ll}\checkmark & \text { Supplementary micronutrients (folic } \\
\text { acid, ferrous sulphate) } \\
\checkmark & \text { Malaria prophylaxis (Sulfadoxine } \\
\text { Pyrimethamine tablets during first, } \\
\text { second and fourth visits) } \\
\checkmark \quad \text { Tetanus toxoid immunization (from } 20 \\
\text { weeks, with second dose four weeks later) }\end{array}$ \\
\hline Client education & $\begin{aligned} \checkmark & \text { Care for health } \\
& 0 \quad \text { Diet and nutrition } \\
& 0 \quad \text { Rest and exercise } \\
& \text { o Personal hygiene } \\
\checkmark & \text { Danger signs during pregnancy } \\
\checkmark & \text { Education on drugs } \\
\checkmark & \text { Purpose of antenatal care } \\
\checkmark & \text { Psychological changes and events in } \\
& \text { pregnancy } \\
\checkmark & \text { Effects of exposure to STDs and } \\
& \text { HIV/AIDS }\end{aligned}$ & $\begin{aligned} & \text { Health promotion } \\
& \quad \text { O Diet and nutrition } \\
& \text { o Rest and exercise } \\
& \text { o Personal hygiene } \\
& \checkmark \text { Danger signs during pregnancy } \\
& \checkmark \text { Education on drugs } \\
& \checkmark \text { Purpose of antenatal care } \\
& \checkmark \text { Psychological changes and events in } \\
& \text { pregnancy } \\
& \checkmark \text { STI/HIV/AIDS prevention } \\
& \checkmark \text { PMTCT } \\
& \checkmark \text { Prevention of malaria } \\
& \checkmark \text { Family planning } \\
& \checkmark \text { Birth preparedness and complication } \\
& \checkmark \text { readiness } \\
& \text { Breastfeeding } \\
&\end{aligned}$ \\
\hline $\begin{array}{l}\text { Treatment of } \\
\text { complications }\end{array}$ & $\begin{array}{ll}\checkmark & \text { Anaemia } \\
\checkmark & \text { Hypertensive disorders } \\
\checkmark & \text { Eclampsia } \\
\checkmark & \text { Malaria } \\
\checkmark & \text { Haemorrhage } \\
\checkmark & \text { Excessive vomiting } \\
\checkmark & \text { Premature rupture of membrane } \\
\checkmark & \text { Urinary Tract Infections } \\
\checkmark & \text { Vulvo-vaginitis } \\
\end{array}$ & $\begin{array}{ll}\checkmark & \text { Anaemia } \\
\checkmark & \text { Hypertensive disorders } \\
\checkmark & \text { Eclampsia } \\
\checkmark & \text { Malaria } \\
\checkmark & \text { Haemorrhage } \\
\checkmark & \text { Excessive vomiting } \\
\checkmark & \text { Premature rupture of membrane } \\
\checkmark & \text { Urinary Tract Infections } \\
\checkmark & \text { Vulvo-vaginitis }\end{array}$ \\
\hline
\end{tabular}




\begin{tabular}{|l|c|c|c|}
\hline \multicolumn{1}{|c|}{ Table 4: Focused ANC services routinely offered in intervention clinics } \\
\hline & $\begin{array}{c}\text { Routinely } \\
\text { offered }\end{array}$ & $\begin{array}{c}\text { Refer to } \\
\text { another } \\
\text { provider in } \\
\text { same clinic }\end{array}$ & $\begin{array}{c}\text { Not } \\
\text { offered }\end{array}$ \\
\hline Counseling on birth plan and emergency preparedness & 10 & - & - \\
\hline Counseling for family planning & 7 & 2 & 1 \\
\hline PMTCT & 7 & 1 & 2 \\
\hline Voluntary counselling about HIV/AIDS & 6 & 3 & 1 \\
\hline Urine test for protein sugar and acetone & 5 & 4 & 1 \\
\hline Tetanus toxoid vaccination & 5 & 5 & - \\
\hline Preventive anti-malarial medication & 5 & 2 & 3 \\
\hline Treatment of STI & 5 & 5 & - \\
\hline Voluntary testing for HIV/AIDS & 3 & 3 & 4 \\
\hline Blood test for anaemia & 2 & 7 & 1 \\
\hline Blood test for syphilis & 1 & 7 & 2 \\
\hline
\end{tabular}

\subsection{The process of stimulating changes in ANC}

The initiative for implementing FANC in Ghana came from JHPIEGO. The model was introduced at a stakeholders' meeting with USAID and other development partners including the WHO, UNFPA, and MOH. Following this, the FANC package was initiated the Tema General Hospital, which was to serve as a model. Tema General Hospital reinvigorated its ANC services by carrying out three major interventions:

1) Introduction of goal-oriented job aids (charts and posters)

2) Introduction of complete and integrated services (including history taking, physical examination, laboratory examinations (blood and urine test and VDRL), measurement of blood pressure, weight, height and temperature, counseling on all health problems, healthy behaviours, and minor discomforts of pregnancy, danger signs, and birth preparedness, IPT, counseling and testing for HIV, ITN and postpartum family planning) to each ANC client

3) Ensuring that the same provider attend to the same client during first and subsequent visits.

In addition, the hospital was re-furbished to be able to provide quality ANC. Each midwife was provided with a fully furnished consulting cubicle; new ANC clients were assigned to a cubicle at their first visit and were expected to receive continuous care from the same midwife in that cubicle at subsequent visits; six midwives attend to six clients at each time decreasing the average time that a client spends at each ANC visit from six hours to two hours. In other clinics, implementation of the focused ANC package was mainly confined to refurbishment of cubicles and staff training, since individualized care is not possible owing to the inadequate number of staff. 
Introduction of the package at the Tema General hospital was reported to show the following positive results 4 :

- Increased ANC attendance

- Early utilization of ANC services by pregnant women

- Reduction in average client waiting time by $1 \mathrm{hr} 40$ minutes

- Individualized care: education and counseling more tuned to client needs

- All care components given by the same provider

- Improved client- provider interaction

- Same provider provides continuing care to the client at all visits

- Increased use of delivery facilities (skilled attendant)

- Decreased still birth rate

- Enhanced use of postnatal care services.

Based on this emerging evidence, the GHS made a decision to pilot test focused ANC at three other regional hospitals in northern Ghana in 2002 and subsequently countrywide. The first step in stimulating changes in ANC across the country was to provide an enabling policy environment for adoption of the WHO focused ANC package; the National Reproductive Health Service Policy and Standards and maternal health cards were revised to reflect the additional components of FANC. The bi-annual meetings of the GHS were used as fora for encouraging Reproductive Health managers across the country to introduce FANC at different levels of care. Managers were advised to re-train all regional resource teams trained in safe motherhood (SM), and these were in turn to train others. At the district level, three persons were selected and trained. This training emphasized a minimum of four ANC client visits, the provision of private and confidential services, comprehensive and individualized care (including individualized counseling, blood pressure, weight and height taking, palpation, urine and blood testing, TT immunization, IPT and PMTCT), and continuous care by the same provider throughout the entire period of pregnancy to enhance the detection of abnormalities. It also stressed birth preparedness and complication readiness, effective referral, advocacy with stakeholders, identification of sources of funding and the preparation of a change plan that looks at infrastructure (e.g., logistics, equipment and supplies), improvement in provider skill, and development of protocols, monitoring and supportive supervision and program evaluation.

At the facility level, ANC services were also to be made available to clients daily. The trained personnel in turn trained the staff and effected the required changes at the facility level. These series of steps are explained in the following statements:

"We talked to RH managers in our biannual meetings and introduced the strategy to them. Some regions picked it up on their own, e.g., Eastern and Ashanti. Eastern is now one of our model areas. Currently what we are doing is we select three people from the district; one from the DHMT and two from the hospital. They are selected such that we always have people in the district who will go back and ensure that the changes take place. Like the district hospital in Tema, we have one of our main master trainers there who was instrumental in ensuring that focused ANC was adopted in the hospital." (Senior Official, Reproductive and Child Health Unit, GHS).

$4 \quad$ Source: Presentation by Dr. Sylvia Deganus (An Obstetrician/Gynaecologist) of the Tema General Hospital at the "Champions for Change: Increasing Maternal and Neonatal Survival" meeting, Accra, 25-30 July, 2004 
One major limitation with getting the package implemented countrywide was the failure of the GHS to have the updated policies widely disseminated. Revision of the service protocol is also yet to happen and the implementation of the package has been made the mandate of the individual service delivery points without committing the necessary resources. Focused ANC in Ghana thus remains an ad-hoc and isolated initiative by a few individual service delivery points.

This notwithstanding, in order to ensure that all regions are offering FANC, the GHS has included FANC in the monitoring guidelines or checklist, and each region is measured against whether it is running FANC or not. GHS also takes the opportunity during the monitoring visits to encourage regions or facilities, which are not practicing it, to do so.

Involvement of critical actors: At the national level, there is a national consultative group, which includes representatives from all the professional groups. These representatives are usually asked to make inputs into policies that are formulated. Therefore, to some extent professional groups such as the Society of Obstetricians and Gynaecologists, Nurses and Midwives Council, and the Ghana Registered Midwives Association have contributed to the development of the policy. With particular reference to FANC, however, some of the representatives of the professional groups mentioned that they were not formally invited to make input to the policy. As remarked by one member of Ghana Registered Midwives Association:

"We have been involved with the formulation of other policies but I don't remember that we saw the policy on FANC even though we have been working with Ministry of Health, and the Ghana Health Service for quite a long time. However, when we entered one of their clinics we found that now they have been labelled 'Client Friendly Focused Antenatal Care' and I was also at Busua Beach when they had their annual meeting so I got to know through the reports that came from the regions."

In spite of this, a representative of the midwifery training schools confirmed that professionals who have benefited from an in-service training on FANC are helping in its introduction by teaching it in the training colleges as an addendum to the training curricula. In addition, these professional groups serve as resource persons in FANC in the regions.

Support for implementing focused ANC: The Government of Ghana is the main financier of reproductive health services. However, there are no specific funds for antenatal care. Regions and districts are expected to use their own internally generated funds to complement whatever is available from central government to support district programmes. They are also expected to make requisition from government stores for equipment needed to carry out the activity. However, because of the competing demands on available resources, regional and district managers allocate the funds according to their perceived needs. According to senior officials of the GHS and districts, the feeling is that:

"... We don't have any specific monies to push it (FANC). We only ask the regions and districts to use their own resources to do that. In addition, we occasionally use some training monies - we are training clinical instructors for the regional hospitals and as part of the logistic training we try to support the hospitals to set up whatever is necessary." (Senior Official, Reproductive and Child Health Unit, GHS) 
"Well, it is the Government of Ghana funds that are still coming in and so it is a matter of prioritizing at one period or the other to ensure that these things come into reality. You really have to do something about the funds that come in and there are many other things too that these same funds have to do, so there should be a way of prioritizing to ensure that these dreams come true." (District Public Health Nurse, Cape Coast)

Several development partners have also provided financial, technical and logistical support to FANC. These include the WHO, UNICEF, UNFPA through EU funding, and EngenderHealth and JHPIEGO through USAID funding. However, the proportion of resources these stakeholders contribute was difficult to ascertain. Support received from health development partners is summarized in Table 5.

\begin{tabular}{|l|l|}
\hline \multicolumn{1}{|c|}{ Table 5: Health partners' support to FANC } \\
\hline \multicolumn{1}{|c|}{ Organization } & \multicolumn{1}{c|}{ Support Provided } \\
\hline WHO & $\begin{array}{l}\text { Development of Guidelines and other } \\
\text { materials }\end{array}$ \\
\hline UNICEF & Provision of essential equipment to the clinics \\
\hline UNFPA/EU & Financial assistance \\
\hline JHPIEGO & $\begin{array}{l}\text { Technical assistance (training, writing of } \\
\text { manuals, presentations), equipment }\end{array}$ \\
\hline EngenderHealth & Financial \\
\hline
\end{tabular}

All stakeholders felt that the $\mathrm{MOH}$ and other local authorities have the capacity to implement FANC and indicated that the rate at which most facilities have embraced the approach, with little available resources, is an indication that there is a desire to implement FANC.

"The rate at which the facilities started putting up infrastructure and the pace at which FANC was started tells me that we are on course." (Public Health Nursing Officer, Greater Accra Region)

Representatives from the donor community also confirmed this, but added concerns regarding supervisory support by programme managers:

"Yes, but what I cannot vouch for is the dedication. Because JHPIEGO trained some people as consultants; all the trainers for reproductive health in the country have been taken through focused ANC. What is left is the dedication of the RCH unit to ensure that supervision is done together with accurate reporting. And when a complication is detected how swift do we go about taking care of this complication so we don't lose this woman? So supervision and monitoring is very important and that is what we don't get and that is why I cannot vouch for the GHS."

\subsection{Clinic preparedness to offer focused ANC}

Clinic preparedness was defined in terms of availability of essential equipment, supplies and appropriate infrastructure to offer focused ANC. An index of clinic preparedness (Table 7) was constructed using five indicators: 
- Availability of essential drugs (Score 0-11): Tetanus toxoid, iron, iron folic, ferrous sulphate, Sulfadoxine Pyrimethamine, contrimodaxizale, amoxycillin, benzathine penicillin/PPF, erythromycin, metronidazale (Flagyl), mebendazole.

- Availability of essential equipment (Score 0-10): Blood pressure gauge, foetoscope, stethoscope, adult scale, measuring tape, thermometer, vaginal speculum (L, M, S), and gynaecological examination table.

- Availability of laboratory supplies (Score 0-10): reagents for urine test for glucose and protein, VDRL/RPR for syphilis, Elisa for HIV-1, Elisa for HIV-2, HIV-rapid test, reagents for anaemia tests, pregnancy test, disposable gloves, and urine specimen bottles.
Table 7: Mean preparedness score by site

\begin{tabular}{|l|c|c|}
\hline \multicolumn{1}{|c|}{ Availability of: } & $\begin{array}{c}\text { Intervention } \\
\text { Clinics } \\
\mathbf{( N = 1 0 )}\end{array}$ & $\begin{array}{c}\text { Control } \\
\text { Clinics } \\
\mathbf{( N = 4 )}\end{array}$ \\
\hline $\begin{array}{l}\text { Essential ANC drugs } \\
\text { (Score 0-11) }\end{array}$ & 9.00 & 10.50 \\
\hline $\begin{array}{l}\text { Essential equipment } \\
\text { (Score 0-10) }\end{array}$ & 7.40 & 6.50 \\
\hline $\begin{array}{l}\text { Essential laboratory } \\
\text { supplies } \\
\text { (Score 0-10) }\end{array}$ & 7.10 & 6.25 \\
\hline $\begin{array}{l}\text { Infrastructure for ANC } \\
\text { consultation (Score 0-6) }\end{array}$ & $5.00^{*}$ & $4.25^{*}$ \\
\hline $\begin{array}{l}\text { Guidelines/reference } \\
\text { materials (Score 0-9) }\end{array}$ & 5.30 & 4.00 \\
\hline Total score (0-46) & $\mathbf{3 3 . 8 0}$ & $\mathbf{3 1 . 5 0}$ \\
\hline$* P<0.05$
\end{tabular}

- Availability of infrastructure (Score 0-6): ANC waiting area, private space for ANC counselling, private space for ANC examination, source of clean water, electricity and laboratory.

- Availability of guidelines, reference manuals, registers, forms and ANC cards on site (Score 0-9): ANC register, standard guidelines/protocol for focused ANC, revised ANC cards, guidelines for PMTCT, Standards and treatment guidelines for Middle Level Health Providers, guidelines for diagnosis treatment and prevention of malaria in pregnancy, focused ANC job aid, malaria in pregnancy job aid, and individual plan pamphlets.

Data were drawn from the clinic assessment tool and mean scores computed for each indicator, and then aggregated across all indicators to give the composite score for clinic preparedness, and compared across intervention and comparison clinics. Overall, there is no significant difference between the clinics, apart from the availability of appropriate infrastructure to support the delivery of focused ANC. Availability of essential ANC drugs was equally high in all clinics, while relevant guidelines/reference materials were not readily available at all clinics. This suggests that introduction of focused ANC was not accompanied by the strengthening of clinic preparedness, except for the clinic refurbishing.

\subsection{Awareness of focused ANC package and services}

Provider awareness of focused ANC: The 34 providers had a range of technical qualifications including: registered nurse with midwifery (15), registered midwife (3), enrolled nurse midwife (6), community health nurse with midwifery (4) and 5 belonged to other medical categories. 
Provider exposure to focused ANC: Table 8 shows the basic training which providers received as part of their technical qualification. Most providers received training on different aspects of focused ANC during pre-service training although these components could have been offered as isolated elements and not part of a comprehensive package.

However, about three quarters of the providers did not have basic training on some key aspects of focused ANC such as counseling for HIV / AIDS infected clients and syphilis screening (RPR) test. The findings show that 3 of the 34 providers interviewed did not personally provide focused ANC services. Of those providing, three-quarters had done this for more than one year and only about half (18) of all providers had received training in focused ANC. Fifty percent (17) of the providers reported that they had received training or orientation on the focused ANC package. When asked how well they knew the guidelines and standards on focused ANC, only 8 providers reported that they knew them very well and 10 reported having only fair knowledge.

Provider's knowledge of focused ANC: Most of the providers (over 80 percent) in the intervention clinics reported detailed knowledge of danger signs in pregnancy, danger signs

\begin{tabular}{|l|c|c|c|}
\hline \multicolumn{4}{|c|}{$\begin{array}{c}\text { Table 9: Providers' own rating of their level of } \\
\text { knowledge of focused ANC components (N= 36) }\end{array}$} \\
\hline \multicolumn{1}{|c|}{ Component } & None & Basic & Detailed \\
\hline Danger signs in pregnancy & - & 2 & 34 \\
\hline Malaria in pregnancy & - & 3 & 33 \\
\hline Anemia in pregnancy & - & 3 & 33 \\
\hline $\begin{array}{l}\text { Comprehensive history } \\
\text { taking }\end{array}$ & 3 & - & 33 \\
\hline $\begin{array}{l}\text { Danger signs during labor, } \\
\text { delivery \& after delivery }\end{array}$ & - & 3 & 33 \\
\hline $\begin{array}{l}\text { The role of birth partners } \\
\text { during ANC }\end{array}$ & 2 & 4 & 30 \\
\hline Antenatal care and STI & 3 & 9 & 24 \\
\hline Individual Birth Planning & 3 & 13 & 20 \\
\hline VCT for HIV & 8 & 10 & 18 \\
\hline PMTCT of HIV & 4 & 15 & 17 \\
\hline
\end{tabular}

Table 8: Proportion of providers with basic training

\begin{tabular}{|l|c|}
\hline \multicolumn{1}{|c|}{ Basic training } & $\begin{array}{c}\text { Providers } \\
\text { N = 34 }\end{array}$ \\
\hline Antenatal care & 34 \\
\hline Management of delivery & 34 \\
\hline Exclusive Breastfeeding & 34 \\
\hline Postnatal care & 33 \\
\hline $\begin{array}{l}\text { Counseling/health education for } \\
\text { maternity clients }\end{array}$ & 32 \\
\hline Post Abortion care & 32 \\
\hline Family planning counseling & 29 \\
\hline Any contraceptive technology & 28 \\
\hline Counseling for prevention of STI & 28 \\
\hline PMTCT of HIV/AIDS & 27 \\
\hline $\begin{array}{l}\text { STI Syndromic management and } \\
\text { treatment }\end{array}$ & 26 \\
\hline Clinical diagnosis \& treatment of STI & 26 \\
\hline Counseling on prevention of PMTCT & 25 \\
\hline $\begin{array}{l}\text { Counseling/social support for } \\
\text { HIV/AIDS infected clients }\end{array}$ & 12 \\
\hline $\begin{array}{l}\text { Medical Management of HIV/AIDS } \\
\text { infected clients }\end{array}$ & 11 \\
\hline $\begin{array}{l}\text { Anti-retroviral therapy for HIV/AIDS } \\
\text { infected clients }\end{array}$ & 11 \\
\hline Syphilis screening (RPR) test & 10 \\
\hline
\end{tabular}

during labour, delivery and after delivery, role of a birth partner, comprehensive history taking, malaria in pregnancy and anaemia in pregnancy, while the greatest areas of weakness were in PMTCT for HIV and VCT for HIV (Table 9). Almost half of the providers considered their knowledge of IBP as basic rather than detailed. When asked about their understanding of focused ANC, providers gave the most appropriate answers including individualized ANC service provision (24) and making four visits for comprehensive care (1). Six providers did not have any specific knowledge about focused ANC. 
When asked about the least number of antenatal visits a woman should make during the entire pregnancy, 30 mentioned four, while six did not give the correct number. Most providers $(97 \%)$ are aware of when the first ( $<16$ weeks) and the fourth (at 36 weeks) visits should be made. However, a negligible proportion (28\%) of the 36 providers mentioned precisely when the second (20-24 weeks) and 36 percent mentioned precisely when the third ( $28-32$ weeks) visits should be made as required under focused ANC.

Knowledge scores on different aspects of focused ANC were low, with an index score of 2.3 (Table 10). Provider's knowledge of PMTCT, IBP and management of syphilis in pregnancy were particularly low but provider knowledge on the prevention of malaria in pregnancy was relatively high. Overall, the introduction of focused ANC did not seem to have any effect on provider knowledge. Half (18) of the providers in the intervention clinics had not received training in focused ANC, but even when the comparison was restricted to those that had received training, the only significant difference was in counseling on PMTCT.

Clients' awareness of focused ANC: Client's awareness of focused ANC was assessed through:

- Knowledge of changes in ANC service delivery;

- Knowledge of different components of focused ANC; and,

- Antenatal care practices in terms clients' timing of ANC visits.

Knowledge of changes in ANC service delivery: Clients' knowledge of changes on ANC and different components of focused ANC were assessed through FGDs. Most clients had not heard about FANC but were more aware of fee exemption for pregnant women. Clients from a few facilities such as Winneba Hospital however, mentioned that their midwife examined them in private instead of through the usual mass examination. Although clients in the Greater Accra region had not heard about FANC, they indicated that they had observed some new elements in antenatal services they receive in recent times.

"Now only one nurse takes care of you, request for your lab results and gives the treatment.

Every cubicle has 2 nurses, if one is not there, the other nurse available attends to you." (ANC Client, Tema Hospital, Greater Accra Region)

Knowledge about the different components of focused ANC: Clients described the different components of FANC and their benefits as follows:

- More client-provider interaction: "There is a lot of improvement because formerly the nurses did not interact freely with us but now they do." (Mother, Tema General Hospital, Greater Accra Region) 
- Individualized care, which ensures privacy, familiarity and confidentiality: "Each client to a nurse is very good and due to that I always long to come to the hospital to see the nurse on my monthly schedule."

"I gave birth at Kumasi but when I came here one nurse took care of me and knows much about my problems. This is good because there is familiarity." (ANC Clients, Tema General Hospital, Greater Accra Region)

- New informative and educative antenatal booklet

- Educational talks

Clients were well informed about the importance of an individual birth plan (IBP). They mentioned that during ANC visits the providers educated them about a list of items they needed to prepare and bring along during delivery. They are also advised by the providers to start saving money towards their delivery and for the care of the new born. Reasons for having an individual birth plan included:

"Birth planning or preparedness is very good because when delivery is due one cannot provide all things needed at a go. I buy the necessary things even before my sixth month to avoid any inconveniences." (ANC Clients, Tema General Hospital, Greater Accra Region)

"You may be faced with an impromptu situation which may affect your finances and if you are not prepared you may face difficulty." (Mother, Adabraka Polyclinic, Greater Accra Region).

\section{Clients' timing of ANC visits:}

The extent to which pregnant women make their visits according to the focused ANC schedule was assessed through a review of clients' observation form (see Table 11). The data indicate that there was a higher tendency for third and fourth visit clients attending the intervention clinics to seek antenatal care at the appropriate time, but there was no significant difference from the control sites. Almost one-third of third visit clients in the intervention clinics sought care between 28 and 32 weeks of gestation compared to 17 percent of those in the comparison clinics. For fourth visit clients, the figures were 7 and 4 percent respectively.

Only eight percent of focused ANC clients

\begin{tabular}{|c|c|c|}
\hline \multicolumn{3}{|c|}{$\begin{array}{l}\text { Table 11: Clients' timing of different ANC } \\
\text { visits as recorded on the observation form }\end{array}$} \\
\hline $\begin{array}{l}\text { Gestation Age } \\
\text { (in weeks) }\end{array}$ & $\begin{array}{c}\text { Intervention } \\
(\%)\end{array}$ & $\begin{array}{c}\text { Comparison } \\
(\%)\end{array}$ \\
\hline $1^{\text {st }}$ visit & $\mathbf{N}=58$ & $\mathrm{~N}=23$ \\
\hline$<16$ & 24 & 26 \\
\hline $16-19$ & 21 & 26 \\
\hline $20+$ & 55 & 48 \\
\hline $2^{\text {nd }}$ visit & $N=61$ & $\mathrm{~N}=\mathbf{2 4}$ \\
\hline$<20$ & 26 & 13 \\
\hline $20-24$ & 43 & 63 \\
\hline $25+$ & 31 & 25 \\
\hline $3^{\text {rd }}$ Visit & $\mathrm{N}=61$ & $\mathrm{~N}=\mathbf{2 4}$ \\
\hline$<28$ & 67 & 79 \\
\hline $28-32$ & 30 & 17 \\
\hline $33+$ & 3 & 4 \\
\hline $4^{\text {th }}$ visit & $N=60$ & $\mathrm{~N}=24$ \\
\hline$<36$ & 90 & 92 \\
\hline 36 & 7 & 4 \\
\hline $36+$ & 3 & 4 \\
\hline
\end{tabular}
were able to give a correct answer when asked about the number of visits an ANC client is expected to make. 


\subsection{Quality of care under focused ANC}

Quality of care was measured using a scale derived from six key components of focused ANC (see Appendix A for the definition of the key components):

- Comprehensive history taking

- Detection of existing diseases

- Prevention of disease and promotion of health

- Birth preparedness and complication readiness

- Postpartum care

- Encouraging continuity of care.

Scores for these components were generated from observations of client-provider interactions during the ANC visits, and a mean score computed for each component and for each visit; these were then compared using statistical significance tests between intervention and comparison clinics.

Table 12 shows that clients visiting the intervention clinics received higher quality of care in the second and fourth visits. However, across the six key components, significant differences were only noted in the care received for prevention of diseases and promotion of health (during first, second and third visits) and encouraging continuity of care. There was no observable effect in the quality of care for comprehensive history taking, birth planning and complication readiness and postpartum care.

\begin{tabular}{|c|c|c|c|c|c|c|c|c|}
\hline \multicolumn{9}{|c|}{ Table 12: Quality of care } \\
\hline \multirow[b]{4}{*}{ Service Component } & \multicolumn{4}{|c|}{ Intervention Clinics } & \multicolumn{4}{|c|}{ Comparison Clinics } \\
\hline & $\mathrm{V}_{1}$ & $\mathrm{~V}_{2}$ & $\mathrm{~V}_{3}$ & $\mathrm{~V}_{4}$ & $\mathrm{~V}_{1}$ & $\mathrm{~V}_{2}$ & $\mathrm{~V}_{3}$ & $\mathrm{~V}_{4}$ \\
\hline & $\operatorname{Max}$ & Max & $\operatorname{Max}$ & $\operatorname{Max}$ & $\operatorname{Max}$ & $\operatorname{Max}$ & $\operatorname{Max}$ & Max \\
\hline & Score $=5$ & Sore $=4$ & Score $=4$ & Score $=4$ & Score $=5$ & Score $=4$ & Score $=4$ & Score $=4$ \\
\hline Comprehensive history taking & 0.62 & - & - & - & 0.68 & - & - & - \\
\hline Detection of existing diseases & 0.47 & 0.50 & 0.56 & $0.57^{* *}$ & 0.51 & 0.44 & 0.51 & $0.48^{* *}$ \\
\hline $\begin{array}{l}\text { Prevention of disease and } \\
\text { promotion of health }\end{array}$ & $0.24^{*}$ & $0.22^{* *}$ & $0.18^{*}$ & 0.17 & $0.16^{*}$ & $0.12^{* *}$ & $0.13^{*}$ & 0.13 \\
\hline $\begin{array}{l}\text { Preparation for birth and } \\
\text { potential complications }\end{array}$ & 0.14 & 0.10 & 0.10 & 0.11 & 0.14 & 0.09 & 0.07 & 0.14 \\
\hline Postpartum care & - & - & 0.03 & 0.02 & - & - & 0.00 & 0.00 \\
\hline Encouraging continuity of care & $0.80^{* *}$ & $0.82^{* *}$ & $0.82^{* *}$ & $0.81^{*}$ & $0.70^{* *}$ & $0.74^{* *}$ & $0.70^{* *}$ & $0.74^{*}$ \\
\hline Total performance & 2.27 & $1.64^{* *}$ & $1.69^{* *}$ & $1.67^{*}$ & 2.19 & $1.41^{* *}$ & $1.40^{* *}$ & $1.50^{*}$ \\
\hline
\end{tabular}

${ }^{* *} \mathrm{p}<0.01 ; \quad{ }^{*} \mathrm{p}<0.05 \quad$ - $=$ Not Applicable

\subsubsection{Comprehensive history taking}

In the intervention clinics, none of the 62 first visit provider-client interactions included all 31 items required for history taking, and only seven $(24 \%)$ of the 29 client-provider interactions with women not in their first pregnancy involved a full enquiry about previous pregnancy history. There was no significant difference between the intervention and comparison clinics in taking history on previous pregnancy. Furthermore, in the intervention clinics, a full inquiry was made into the danger signs experienced with the pregnancy in five $(8 \%)$ of the first visit interactions observed, while a partial enquiry was made in 60 percent of the cases; in about a third of the first visit interactions no enquiries at all were made. 
No full enquiries were made into the danger signs of pregnancy during the second, third and fourth visits in the intervention clinics, and partial enquiries ranged from 60 percent for first visit clients to 100 percent for fourth visit clients. Providers in the comparison clinics were less likely to inquire into the danger signs experienced during the pregnancy even though this is part of the traditional ANC procedures.

\subsubsection{Detection of existing diseases}

Not all the procedures required to detect diseases in pregnancy were followed. For example, blood samples for laboratory analysis, measuring blood pressure and palpating for fundal height for first visit clients were the only procedures that were carried out routinely in both the intervention and comparison clinics (Table B1, Appendix B). For the second, third and fourth visits, comparatively more clients in the intervention than the comparison clinics were given a general physical examination and had their weight and blood pressure taken. The intervention clinics performed significantly better in conjunctiva and palm checking for anaemia and observation of general appearance in all subsequent visits. Abdominal listening for foetal sounds happened more often in the comparison group than in the intervention group for second and third visits, although the difference was not significant.

Clinical investigations were generally low in both groups, and generally lower in the intervention than in the comparison clinics (Table 13). Referrals for HIV test were either nonexistent or far less satisfactory for all visits in both groups. Referrals for a urine test were, however, significantly higher in the comparison group for first and second visits. The main reason for this poor performance was the irregular supply of test reagents, and the nonavailability of such HIV services in the facilities themselves.

Table 13: Proportion of clients receiving laboratory investigations during ANC visits

\begin{tabular}{|c|c|c|c|c|c|c|c|c|}
\hline & \multicolumn{4}{|c|}{ Intervention (\%) } & \multicolumn{4}{|c|}{ Comparison (\%) } \\
\hline Investigations & $\begin{array}{c}\mathrm{V}_{1} \\
\mathrm{~N}=62\end{array}$ & $\begin{array}{c}\mathrm{V}_{2} \\
\mathrm{~N}=62\end{array}$ & $\begin{array}{c}V_{3} \\
N=61\end{array}$ & $\begin{array}{c}\mathrm{V}_{4} \\
\mathrm{~N}=60\end{array}$ & $\begin{array}{c}\mathrm{V}_{1} \\
\mathrm{~N}=24\end{array}$ & $\begin{array}{c}\mathrm{V}_{2} \\
\mathrm{~N}=24\end{array}$ & $\begin{array}{c}V_{3} \\
N=24\end{array}$ & $\begin{array}{c}\mathrm{V}_{4} \\
\mathrm{~N}=24\end{array}$ \\
\hline Urine tests & $52^{*}$ & 35 & 34 & 42 & $92^{*}$ & 17 & 50 & 33 \\
\hline HIV tests (earliest opportunity) & 0.0 & 2 & 3 & 0.0 & 0.0 & 4 & 0.0 & 0.0 \\
\hline Anaemia test (visit 1 only) & $21^{* *}$ & - & - & - & $79^{* *}$ & - & - & - \\
\hline $\begin{array}{l}\text { Syphilis test (VDRL) } \\
\text { (visit } 1 \text { only) }\end{array}$ & $2^{* *}$ & - & - & - & $29^{* *}$ & - & - & - \\
\hline Blood test for haemoglobin & $22^{* *}$ & - & - & 10 & $79^{* *}$ & - & - & 29 \\
\hline
\end{tabular}

\subsubsection{Prevention of diseases and promotion of health}

A comparison of the intervention and comparison clinics shows significant differences in the provision of services related to the prevention of disease and promotion of health during the second and third visits (Table B2, Appendix B).

Prevention of anaemia, tetanus and malaria in pregnancy: Providers frequently prescribed iron tablets and folic acid but this was not accompanied by appropriate explanation on how to take them and the purpose for taking them; this was common across all visits in both groups. Apart 
from tetanus toxoid injections, all other procedures were performed during less than fifty percent of the client-provider interactions, with the intervention clinics performing marginally better across board (Table B2, Appendix B).

Counseling on STI/HIV/AIDS: The proportions of clients who received counseling on specific STI/HIV topics were far less than optimal for both groups for all visits (Table B3, Appendix B). Most clinics still provide counseling through mass educational talks during waiting time rather than with individual clients. This situation probably explains the generally low level of individual counseling of clients observed in both groups, though this is slightly better in the intervention clinics.

Counseling on danger signs in pregnancy and self-care during pregnancy: The proportion of clients who received counseling on danger signs during pregnancy was far less than half for both groups during all visits, except for counseling on diet, where the intervention clinics performed significantly better than the comparison during the second and fourth visits (Table B4, Appendix B).

\subsubsection{Preparation for birth and potential complications}

The only major feature of birth preparation and complication readiness given due attention by any providers was informing clients about progress of the pregnancy, for which the intervention group was better during the first visit. Advice to clients about supplies to have on hand at home was mainly given during the first visit, and significantly higher in the comparison group (Table B5, Appendix B).

\subsubsection{Counselling on postpartum care}

Advice on use of family planning after delivery, referral to a family planning clinic, making a visit to a postpartum clinic, and to a well-baby clinic for immunization, was virtually non-existent in both study groups (Table B6, Appendix B).

\subsubsection{Consultation to encourage continuity in care}

Half the clients seen at the intervention clinics had only one provider contact, compared to less than a quarter in the comparison group (Figure 1). These results clearly demonstrate the significant reduction in contacts per visit, leading to more individualized care. With the exception of informing clients about the due date of delivery, and to some extent, telling them about what was to be done, both intervention and comparison clinics

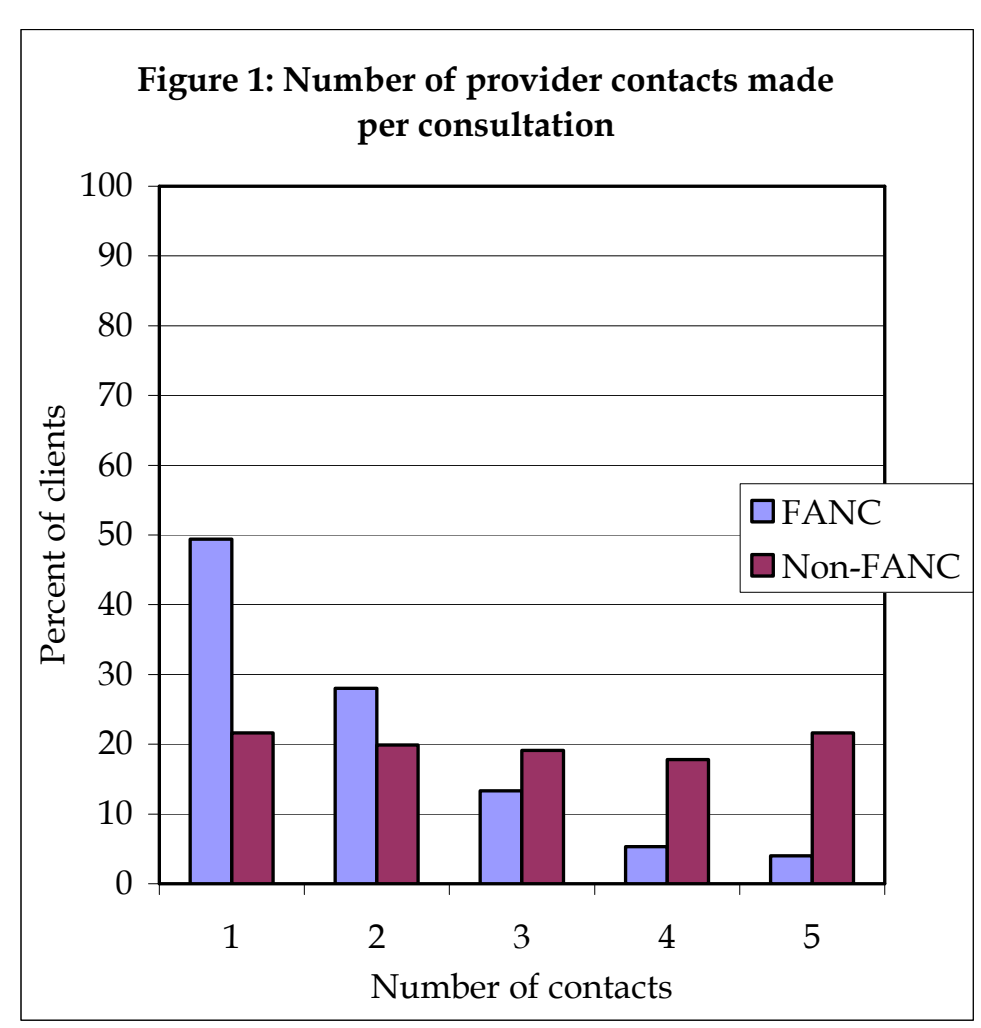


performed fairly well for all other items across all visits (Table B7, Appendix B).

\subsubsection{Client satisfaction with focused ANC services}

The majority of clients in both the comparison and intervention clinics were satisfied with all the services received, but fewer found waiting time satisfactory (Table 14), although there was no significant difference between the intervention and comparison clinics ( 1 hour 45 minutes vs. 1 hour 25 minutes respectively). But as stated by one informant:

"When you decide to come for ANC you should be prepared that even if you spend the whole day you will be seen.... sometimes we keep long but am not bothered."

(ANC Client, Winneba Hospital, Central Region).

Overall, satisfaction levels were higher for clients in the intervention clinics than for those in the comparison clinics, with significant differences being noted for "ability to discuss problems", "amount of explanation given about a problem" and "quality of examination and treatment provided."

\begin{tabular}{|l|c|c|c|c|c|c|}
\hline \multicolumn{1}{|c|}{ Table 14: Proportion of client satisfied with various aspects of focused ANC services } \\
\hline & \multicolumn{3}{|c|}{$\begin{array}{c}\text { Intervention clinics (\%) } \\
\text { (N=257) }\end{array}$} & \multicolumn{3}{c|}{$\begin{array}{c}\text { Comparison clinics (\%) } \\
\text { (N=85) }\end{array}$} \\
\hline & Satisfied & $\begin{array}{c}\text { Not } \\
\text { Satisfied }\end{array}$ & Undecided & Satisfied & $\begin{array}{c}\text { Not } \\
\text { Satisfied }\end{array}$ & Undecided \\
\hline Waiting time & 61.5 & 37.4 & 1.2 & 57.6 & 41.2 & 1.2 \\
\hline $\begin{array}{l}\text { Ability to discuss } \\
\text { problems }\end{array}$ & $95.7^{* *}$ & 3.9 & 0.4 & $80.0^{* *}$ & 16.5 & 3.5 \\
\hline $\begin{array}{l}\text { Explanation received } \\
\text { about a problem }\end{array}$ & $96.9^{* *}$ & 1.6 & 1.6 & $81.2^{* *}$ & 18.8 & 0.0 \\
\hline $\begin{array}{l}\text { Quality of examination } \\
\text { and treatment }\end{array}$ & $99.2^{*}$ & 0.4 & 0.4 & $95.3^{*}$ & 4.7 & 0.0 \\
\hline Cleanliness of facility & 98.0 & 1.6 & 0.4 & 97.6 & 2.4 & 0.0 \\
\hline Treatment by staff & 98.4 & 1.2 & 0.4 & 98.8 & 1.2 & 0.0 \\
\hline $\begin{array}{l}\text { Mean overall satisfaction } \\
\text { score (Max=5) }\end{array}$ & $4.5^{* *}$ & & & $4.1^{* *}$ & \\
\hline
\end{tabular}

${ }^{* *} \mathrm{p}<0.01 ; \quad{ }^{*} \mathrm{p}<0.05$

Most clients had no major concerns with the antenatal care services they received; indeed, they were full of praise for the services they received and concluded that the client-provider relationship was very cordial:

"Now only one nurse takes care of you, request for your lab results and gives the treatment. Every cubicle has 2 nurses, if one is not there, the other nurse available attends to you." (ANC Client, Tema General Hospital, Greater Accra Region).

Much as clients from both regions expressed satisfaction with the new antenatal services, they were also quick to add that there was room for improvement. Most were particularly emphatic that they would prefer their facilities to supply them with drugs rather than having to buy them from outside the facilities, as this was inconvenient and more expensive. Clients from the Greater Accra region also expressed the desire for laboratory fees to be reduced, whereas clients from the Central region raised the issue of shortage of antenatal cards. 


\subsubsection{Provider Satisfaction with focused ANC}

Virtually all (96\%) providers approved the changes in the provision of ANC services, mentioning several practical benefits of FANC:

1. Client-provider relationship is enhanced, creating confidence in the midwife, so that clients are able to voice their problems:

"In doing this you know the client very well, her problems and how well to solve them and she also knows you and can confide in you..."

(FGD: Swedru/Kasoa Private Provider, Central Region)

2. Increased numbers of ANC clients due to better quality of care: Providers felt that the quality of services offered to clients under focused ANC is good, and that this has resulted in higher numbers attending for services. They explained that the opportunity for one midwife to see a client from pregnancy till delivery has positive consequences, as the client is treated based on her peculiar situation and hence foreseen complications can be well managed on time.

"ANC new attendance used to be 100. Now new attendants can be like 200 people a month. Today is March 17th and the new people number about 520 people from January until now." (Provider, Ashaiman Health Centre, Greater Accra Region)

\section{Positive change of attitude of providers:}

"The quality is good. The number of antenatal, deliveries and everything has increased"

(Provider, Saltpond/ Abura Dunkwa, Central Region)

"... client attendance is quite good and even staff attitude has changed considerably."(Provider, Winneba Hospital, Central Region)

Providers' willingness to provide FANC services was very high in both regions, as evidenced by facilities implementing the services in the midst of limited and over stretched resources. All providers from the two regions, in both public and private health institutions, were unanimous about their willingness and commitment to practice FANC. In particular, private midwives described the concept as "their usual way of delivering antenatal service." The reasons given for desiring to provide focused antenatal care are as follows:

- Adequate time to better assess clients

- Client confidence in provider

"If our interpersonal relationship with the client is cordial she will gain confidence in us and this will help the work to go on."

(Provider, Kasoa Health Centre, Central Region)

- Potential to reduce maternal complications and early detection of abnormality

"As we have said, with the new one because you will get to know every detail about

the client, if she develops a complication you will notice it before it becomes worse. It also reduces waiting time."

(Provider, Kasoa Health Centre, Central Region)

- Encouraging higher clinic attendance by clients

"We prefer it because it encourages pregnant women to come to ANC."

(Provider, Ashaiman Health Centre, Greater Accra Region)

- Makes service providers more responsible towards their clients 
"We want the new one. It helps us to be responsible. If we continue to practice the old type of ANC I will not be responsible because they cannot call me directly to say I am responsible for the client. But with FANC, I will be alert to make sure I do the right thing so that at the end of the day I will not be called to answer."

(Provider, Kaneshie Polyclinic, Greater Accra Region)

- Job satisfaction/ fulfilment

The new approach is the best although it is tiring.... but when you are able to give your client the best and they get satisfied you also get satisfied."

(Provider, Winneba Hospital, Central Region)

"We are happy with it because you take care of the patient from pregnancy to delivery... and you have achieved your aim by helping someone deliver safely."

(Provider, Cape Coast, Central Region)

\section{Discussion}

The Ministry of Health/Ghana Health Services is committed to focused antenatal care and has introduced several components of the strategy within the national reproductive health policy and standards. To ensure that all regions in the country implement the strategy, the GHS has also made focused antenatal care part of its monitoring guidelines and checklist and each region is assessed as to whether it is providing focused antenatal care or not.

Although a number of stakeholders were instrumental in getting the new approach adopted as a national strategy by the GHS, the planning process for its introduction was not sufficiently consultative. Some professional organizations and training institutions have not been involved; its introduction has been through using the bi-annual meetings of the GHS as a forum for encouraging Reproductive Health managers across the country to introduce the new approach. This would explain the variation in the levels of implementation across facilities, even within the same region.

The enthusiasm to implement the strategy has not been matched with commensurate resources allocated by the national level, and regions and districts are expected to use their own internally generated funds to put in place any additional structures and equipment required. The Ministry has no special budgetary allocation earmarked for it because, within the context of the sectorwide approaches, budget allocations and expenditures are not made on the basis of specific programmes, but according to the strategic objectives of the health sector. It is, therefore, not possible to determine the proportion of the health budget allocated to reproductive health activities, and in particular FANC. However, overall resource allocation for service delivery is a small proportion of the health sector budget (see Birungi et al 2006), which makes comprehensive implementation of FANC difficult. For example, some facilities in Greater Accra have not been able to implement the whole package even though their focal persons have received the necessary training. External support for FANC has been piecemeal and limited to technical assistance, such as funding for training. Facilities clearly require more than training support to implement even the minimum changes needed.

Training of staff has been ad hoc, with training provided as isolated elements over time and not as part of a comprehensive package. Moreover, half of the providers in the intervention clinics 
had not received any additional training or orientation in FANC. A related challenge is the manner in which providers are selected for training, with the perception that the appropriate people, such as focal persons for ANC, are sometimes left out of training. Poor provider knowledge may be linked to the poor distribution of guidelines and protocols for providing all components of focused ANC; indeed, most providers were not aware of the counseling information that they should give to pregnant women on PMTCT.

Focusing ANC has resulted in significantly better quality of care, notably in prevention of diseases and promotion of health and encouraging continuity of care. Clients visiting the intervention clinics obtained more comprehensive care than those visiting the comparison clinics. However, introduction of FANC has had no effect on comprehensive history taking, birth planning and complication readiness and postpartum care.

Community sensitization about FANC has been virtually non-existent. No conscious effort has been made to raise community awareness, thus ruling out opportunities for those who do not seek ANC services at the facilities to know about it, and especially the need for four visits, each with services specific to the stage of pregnancy. Clients' knowledge of the content of FANC was poor and usually confused with the recently introduced policy for free delivery services. Nevertheless, clients were able to describe some changes that typify limited components of FANC, such as individualized care and privacy, and were quite knowledgeable about the individual birth plan. Such information is provided as part of the group education preceding consultations, which does not address the individual knowledge needs of clients.

The GHS identifies human resources to be a major challenge to the sustainability of FANC. Inadequate numbers of trained personnel for ANC generally has been a longstanding and systemic problem, and the high attrition rate of the few trained staff has worsened the situation. In the short term, providing in-service training on FANC may help ease the burden on the few providers who have been trained to offer the service, and as a long-term measure there are suggestions to incorporate FANC into pre-service training curricula.

The physical infrastructure, equipment and supplies within facilities are also a challenge. Most facilities are partitioning their existing consulting rooms to make space for more cubicles that can allow individualized consultations, but without the accompanying equipment and services needed for all component services, the care provided will not be comprehensive.

\section{Conclusion and Recommendations}

Official support for focused ANC is very high, as demonstrated by its inclusion in the national reproductive health service policy. The package has also been well accepted by both clients and providers because of its comprehensiveness and individualized care. In addition, providers are willing to deliver the services as long as the required logistical support is provided, including standard guidelines and job aids. Successful implementation of the package also depends on the competence of providers, and there is the need for a more systematic approach to training providers on many components of the service package. The basic principles of focused ANC, with specific emphasis on scheduling of visits, VCT and links with PMTCT should be emphasized. The content, duration and selection of providers for training should also be critically examined. 
Although the policy clearly specifies the various components of the package, the guidelines for its implementation have not been widely distributed. The process of stimulating changes in focused ANC service delivery will need further consultation with the pre-service training institutions and professional bodies to ensure its institutionalization, as well as updating the curricula for pre-service training institutions. For FANC services to be offered as planned, current providers will have to be offered more comprehensive in-service training on the complete range of recommended services.

Community-level education is also required to create awareness about the timing of ANC visits, individual birth planning, advice on danger signs and self-care in pregnancy, complication preparedness and the need to involve other family members in birth planning.

\section{Utilization of Study Findings}

The findings of this study were first presented at a dissemination meeting held in November 2005, attended by 35 stakeholders from the Ghana Health Service and the Ministry of Health, Nursing and Midwifery Training Schools, Ghana Registered Midwives Association (GRMA), UNFPA, Quality Health Partners, USAID, Population Council and representatives from the participating institutions. Recommendations made at this meeting include:

- The need for national policy guidelines/protocols on implementing FANC.

- An assessment of the effect of client-workload on quality of care.

- The need to design a standard list of equipment and supplies to be procured for facilities implementing FANC.

- Support for members of GRMA to enable them to fully implement FANC in their facilities.

- The need to foster a private-public partnership to ensure implementation of the policy by all stakeholders.

A technical committee comprising of tutors from the various pre-service nursing training schools, the rural health training school and a representative from the CHPS/TA Project was set up in August 2005 to review all nursing training curricula (for the registered general nursing diploma programme; community health nursing diploma and certificate programmes, the midwifery diploma, and post-basic and basic programmes) and to incorporate FANC and other emerging policy issues into these curricula. To aid their discussions, facilitators have been invited to make presentations to the committee on emerging topics such as FANC and STI management. This process is ongoing, with the expectation that the revised curricula will come into effect in the last quarter of 2006. 


\section{References}

Birungi, H., E.Addai, G.Addico, C. Jehu-Appiah, P. Nyarko, I. Askew, and A. Ajayi. 2006. Health Sector Reforms in Ghana and Implications for Reproductive Health Priority Setting. FRONTIERS final Report, Washington DC, Population Council.

Ghana Health Service (2002) Maternal Health/Death Audit Guidelines, Reproductive and Child Health Unit, Public Health Division, Ghana Health Service, 2002

Ghana Health Service (2003) HIV Sentinel Survey Report 2003, National AIDS/STI Control Programme, Ghana Health Service, March 2003.

Ghana Health Service (2003) National Reproductive Health Service Policy and Standards: Second Edition, December 2003.

Ghana Health Service (2003) Annual Report, Reproductive and Child Health Unit, Public Health Division, Ghana Health Service, 2003

Ghana Health Service (2004) Annual Report, Reproductive and Child Health Unit, Public Health Division, Ghana Health Service, 2004

Ghana Statistical Service (GSS), Noguchi Memorial Institute for Medical Research (NMIMR), and ORC Macro (2004), Ghana Demographic and Health Survey 2003, Calverton, Maryland: GSS, NMIMR, and ORC Macro

Ghana Statistical Service, Health Research Unit, Ministry of Health Ghana Service Provision Assessment Survey (2002) Calverton, Maryland: GSS, HRU/MOH, and ORC.

Janowitz, John H. Bratt 1994. Methods for Costing Family Planning Services, FHI.

UNFPA and MOH 2004 Ghana Health Sector Five-Year Programme of Work 2002-2006: An Indepth Review of the Health Sector Response to Maternal Mortality in Ghana by 2003.

Miller, R., Fisher A, Miller K, Ndhlovu L, Maggwa BN, Askew I, et al. (1997) The Situation Analysis Approach to Assessing Family Planning and Reproductive Health Services: A Handbook, Population Council, New York: USA

Valadez JJ, Transgrud R, Mbugua M and Smith T (1997) “Assessing Service-delivery Skills in Kenya", Studies in Family Planning, 28, 2:143-150.

Villar J, Ba'aqeel H, Piaggio G, Lumbiganono P, Belizan JM, Farnot U, Al-Mazrou Y, Carroli G, Pino A, Donner A, Langer A, Nigenda G, Mugford M, Fox-Rushby J, Hutton G, Bergsjo $\mathrm{P}$, Berebdes H. 2001. "WHO antenatal care randomized trial for the evaluation of a new model of routine antenatal care", The Lancet, 357: 1565-1570.

Walt G and Gilson L (1994) Reforming the Health Sector in Developing Countries: The Central Role of Policy Analysis. Health Policy and Planning, 9: 353 - 370. 


\section{Appendix A: Definition of quality of care indicators}

Comprehensive history taking involves recording a client's personal, family and social history as well as her current and previous pregnancy history during the first visit. As part of this client information, the provider is to inquire about the client's contraceptive history, medication currently being taken, alcohol use and smoking, HIV status, general health problems, and history of complaints and danger signs in current pregnancy.

Detection of existing diseases: Items for measuring this indicator include observing the general appearance of clients, carrying out physical examinations, and conducting or referring clients for specific laboratory investigations considered useful for detecting existing diseases during each visit.

Prevention of disease and promotion of health: This indicator covers a range of counseling and treatment services including prescribing iron and folic acid tablets to clients and explaining their purpose, explaining the use of insecticide-treated bed nets (ITN) and counseling clients on STI/HIV specific issues, danger signs in pregnancy and self-care at each visit. On the second and third visits, providers are expected to give, in addition to these, TT injection, explain its purpose, ask if clients are allergic to SP, give anti-malarial prophylaxis $\left(1^{\text {st }}\right.$ dose during $2^{\text {nd }}$ trimester and $2^{\text {nd }}$ and $3^{\text {rd }}$ doses during the third trimester), explain the purpose of SP and how to take it, and the importance of coming back for the second and third doses. The provider is also required to ask about the side effects from the first dose of SP before giving the second dose.

Preparation for birth and potential complications: Under this component, providers are expected to inform the client about the due date and progress of pregnancy, inquire about where she plans to deliver and which health care facility she desires to use in case of complication, identify the person who will care for the family during delivery, advice client to use a skilled health worker, discuss birth partners and the need to involve them in the preparation of the individual birth plan, ask the client about her financial arrangements and advise her on supplies to have on hand at home at all visits.

Counseling on postpartum care: This indicator is based on whether provider advised clients to use family planning after delivery and to visit the postpartum clinic, whether provider discussed the importance of immunization for new born and advised clients to visit the well baby clinic, and whether the provider advised the client on care of breast and exclusive breastfeeding during the third and fourth visits.

Encouraging continuity of care: This indicator measures the extent to which consultations encourage rapport and ensure continuity of care. Items scored include whether provider ensured client's privacy and confidentiality during consultation, and whether clients were told what was to be done and encouraged to raise any concerns or ask questions at all visits. 


\section{Appendix B: Tables}

\begin{tabular}{|l|c|c|c|c|c|c|c|c|}
\hline \multicolumn{7}{|c|}{ Table B1: Proportion of client -provider interaction where clients received observations, physical } \\
examinations and referrals \\
\hline
\end{tabular}

${ }^{* *} \mathrm{p}<0.01 ; \quad$ " $\mathrm{p}<0.05 \quad-=$ Not Applicable 


\begin{tabular}{|c|c|c|c|c|c|c|c|c|}
\hline \multicolumn{9}{|c|}{ Table B2: Prevention of diseases in pregnancy } \\
\hline \multirow[b]{2}{*}{ Service Component } & \multicolumn{4}{|c|}{ Intervention (\%) } & \multicolumn{4}{|c|}{ Comparison (\%) } \\
\hline & $\begin{array}{c}\mathrm{V}_{1} \\
(\mathrm{~N}=62)\end{array}$ & $\begin{array}{c}\mathrm{V}_{2} \\
(\mathrm{~N}=62)\end{array}$ & $\begin{array}{c}\mathrm{V}_{3} \\
(\mathrm{~N}=61)\end{array}$ & $\begin{array}{c}\mathrm{V}_{4} \\
(\mathrm{~N}=60)\end{array}$ & $\begin{array}{c}\mathrm{V}_{1} \\
(\mathrm{~N}=24)\end{array}$ & $\begin{array}{c}\mathrm{V}_{2} \\
(\mathrm{~N}=24)\end{array}$ & $\begin{array}{c}\mathrm{V}_{3} \\
(\mathrm{~N}=24)\end{array}$ & $\begin{array}{c}\mathrm{V}_{4} \\
(\mathrm{~N}=24)\end{array}$ \\
\hline $\begin{array}{l}\text { Prescribe or give client } \\
\text { iron/folic acid tablets }\end{array}$ & 98.4 & 96.8 & $98.4^{*}$ & 91.7 & 100 & 100 & $87.5^{*}$ & 91.7 \\
\hline $\begin{array}{l}\text { Explain purpose of } \\
\text { iron or folic acid }\end{array}$ & 44.3 & $41.0^{* *}$ & 34.4 & 36.7 & 54.2 & $4.2^{* *}$ & 16.7 & 25.0 \\
\hline $\begin{array}{l}\text { Explain how to take } \\
\text { iron or folic acid }\end{array}$ & 72.1 & 74.2 & 72.1 & 63.3 & 79.2 & 83.3 & 79.2 & 79.2 \\
\hline $\begin{array}{l}\text { Provide counseling } \\
\text { about the use of ITN }\end{array}$ & 8.2 & 6.6 & 4.9 & 5.0 & 0.0 & 0.0 & 0.0 & 0.0 \\
\hline $\begin{array}{l}\text { Ask client if allergic to } \\
\text { SP before prescribing }\end{array}$ & - & 12.9 & - & - & - & 12.5 & - & - \\
\hline $\begin{array}{l}\text { Explain purpose of } \\
\text { preventive treatment } \\
\text { with anti-malarial } \\
\text { medication }\end{array}$ & - & $14.8^{*}$ & 13.1 & - & - & $0.0^{*}$ & 0.0 & - \\
\hline $\begin{array}{l}\text { Prescribe or give anti- } \\
\text { malarial prophylaxis - } \\
1^{\text {st }}, 2^{\text {nd }}, 3^{\text {rd }} \text { dose of SP }\end{array}$ & - & 35.5 & 26.2 & 23.3 & - & 20.8 & 25.0 & 16.7 \\
\hline $\begin{array}{l}\text { Explain how to take } \\
\text { anti-malarial } \\
\text { medication }\end{array}$ & - & $25.8^{*}$ & $24.6^{* *}$ & - & - & $4.2^{*}$ & $0.0^{* *}$ & - \\
\hline $\begin{array}{l}\text { Explain the } \\
\text { importance of coming } \\
\text { back for } 2^{\text {nd }} \text { dose }\end{array}$ & - & 9.8 & & - & - & 0.0 & & - \\
\hline $\begin{array}{l}\text { Ask client about side } \\
\text { effects from } 1^{\text {st }} \& 2^{\text {nd }} \\
\text { dose of SP }\end{array}$ & - & & 4.9 & 8.3 & - & 0.0 & 0.0 & - \\
\hline $\begin{array}{l}\text { Give tetanus toxoid } \\
\text { injection }\end{array}$ & - & 50.8 & 37.7 & - & - & 54.2 & 29.2 & - \\
\hline $\begin{array}{l}\text { Explain the purpose of } \\
\text { tetanus toxoid } \\
\text { injection }\end{array}$ & - & $31.1^{* *}$ & 24.6 & - & - & $0.0^{* *}$ & 16.7 & - \\
\hline
\end{tabular}




\begin{tabular}{|c|c|c|c|c|c|c|c|c|}
\hline \multirow[b]{2}{*}{$\begin{array}{l}\text { Counseling on } \\
\text { STI/HIV }\end{array}$} & \multicolumn{4}{|c|}{ Intervention $\%$} & \multicolumn{4}{|c|}{ Comparison \% } \\
\hline & $\begin{array}{c}\mathrm{V}_{1} \\
(\mathrm{~N}=62)\end{array}$ & $\begin{array}{c}\mathrm{V}_{2} \\
(\mathrm{~N}=62)\end{array}$ & $\begin{array}{c}\mathrm{V}_{3} \\
(\mathrm{~N}=61)\end{array}$ & $\begin{array}{c}\mathrm{V}_{4} \\
(\mathrm{~N}=60)\end{array}$ & $\begin{array}{c}\mathrm{V}_{1} \\
(\mathrm{~N}=24)\end{array}$ & $\begin{array}{c}\mathrm{V}_{2} \\
(\mathrm{~N}=24)\end{array}$ & $\begin{array}{c}\mathrm{V}_{3} \\
(\mathrm{~N}=24)\end{array}$ & $\begin{array}{c}\mathrm{V}_{4} \\
(\mathrm{~N}=24)\end{array}$ \\
\hline $\begin{array}{l}\text { Discussed STI } \\
\text { symptoms and signs }\end{array}$ & 11.3 & 9.8 & 3.3 & 3.3 & 0.0 & 0.0 & 0.0 & 0.0 \\
\hline $\begin{array}{l}\text { Discussed side effects } \\
\text { of STI/HIV/AIDS in } \\
\text { pregnancy }\end{array}$ & $16.1^{*}$ & 9.7 & 6.6 & 5.0 & $0.0^{*}$ & 0.0 & 0.0 & 0.0 \\
\hline $\begin{array}{l}\text { Asked clients about } \\
\text { presence of STI/HIV } \\
\text { symptoms }\end{array}$ & 12.9 & 8.1 & 1.6 & 3.3 & 0.0 & 0.0 & 0.0 & 0.0 \\
\hline $\begin{array}{l}\text { Discussed STI/HIV } \\
\text { risk factors }\end{array}$ & $17.7^{*}$ & 9.7 & 6.6 & 8.3 & $0.0^{*}$ & 0.0 & 0.0 & 0.0 \\
\hline $\begin{array}{l}\text { Inquired from client } \\
\text { about their STI/HIV } \\
\text { risk factors }\end{array}$ & $19.7^{*}$ & 11.3 & 1.6 & 8.3 & $0.0^{*}$ & 0.0 & 0.0 & 0.0 \\
\hline $\begin{array}{l}\text { Discussed how to } \\
\text { prevent STI/HIV }\end{array}$ & $19.4^{*}$ & 6.5 & 4.9 & 8.3 & $0.0^{*}$ & 0.0 & 0.0 & 0.0 \\
\hline $\begin{array}{l}\text { Discussed the use of } \\
\text { condoms during } \\
\text { pregnancy }\end{array}$ & 9.7 & 3.2 & 0.0 & 5.0 & 0.0 & 0.0 & 0.0 & 0.0 \\
\hline $\begin{array}{l}\text { Provided information } \\
\text { on PMTCT of HIV }\end{array}$ & 12.9 & 4.8 & 3.3 & 3.3 & 0.0 & 0.0 & 0.0 & 0.0 \\
\hline $\begin{array}{l}\text { Discussed } \\
\text { opportunities to } \\
\text { reduce PMCT of HIV }\end{array}$ & 11.3 & 4.8 & 3.3 & 3.3 & 0.0 & 0.0 & 0.0 & 0.0 \\
\hline $\begin{array}{l}\text { Discussed VCT and its } \\
\text { advantages }\end{array}$ & $14.5^{*}$ & 12.9 & 6.6 & 3.3 & $0.0^{*}$ & 0.0 & 0.0 & 0.0 \\
\hline $\begin{array}{l}\text { Discussing where to } \\
\text { go for VCT services }\end{array}$ & $16.1^{*}$ & 12.9 & 8.2 & 5.0 & $0.0^{*}$ & 0.0 & 0.0 & 0.0 \\
\hline $\begin{array}{l}\text { Discussed clients' } \\
\text { interest in getting VCT } \\
\text { services }\end{array}$ & $14.5^{*}$ & 12.9 & 6.6 & 5.0 & $0.0^{*}$ & 0.0 & 0.0 & 0.0 \\
\hline $\begin{array}{l}\text { Referred client to } \\
\text { another facility for } \\
\text { VCT }\end{array}$ & 0.0 & 1.6 & 0.0 & 0.0 & 0.0 & 0.0 & 0.0 & 0.0 \\
\hline
\end{tabular}




\begin{tabular}{|c|c|c|c|c|c|c|c|c|}
\hline \multirow[b]{2}{*}{ Service Component } & \multicolumn{4}{|c|}{ Intervention (\%) } & \multicolumn{4}{|c|}{ Comparison (\%) } \\
\hline & $\begin{array}{c}\mathrm{V}_{1} \\
(\mathrm{~N}=62)\end{array}$ & $\begin{array}{c}\mathrm{V}_{2} \\
(\mathrm{~N}=62)\end{array}$ & $\begin{array}{c}\mathrm{V}_{3} \\
(\mathrm{~N}=61)\end{array}$ & $\begin{array}{c}\mathrm{V}_{4} \\
(\mathrm{~N}=60)\end{array}$ & $\begin{array}{c}\mathrm{V}_{1} \\
(\mathrm{~N}=24)\end{array}$ & $\begin{array}{c}\mathrm{V}_{2} \\
(\mathrm{~N}=24\end{array}$ & $\begin{array}{c}\mathrm{V}_{3} \\
(\mathrm{~N}=24)\end{array}$ & $\begin{array}{c}\mathrm{V}_{4} \\
(\mathrm{~N}=24)\end{array}$ \\
\hline Vaginal bleeding & 27.9 & $25.8^{\star *}$ & 26.2 & 20.3 & 37.5 & $0.0^{* *}$ & 16.7 & 25.0 \\
\hline Fever & 26.7 & 24.2 & $11.5^{*}$ & 18.6 & 25.0 & 25.0 & $29.2^{*}$ & 29.2 \\
\hline $\begin{array}{l}\text { Excessive tiredness or } \\
\text { breathlessness }\end{array}$ & $20.0^{*}$ & $16.1^{*}$ & $14.8^{\star}$ & 8.5 & $0.0^{*}$ & $0.0^{*}$ & $0.0^{*}$ & 0.0 \\
\hline $\begin{array}{l}\text { Swollen hands, face, } \\
\text { legs }\end{array}$ & 19.7 & $14.5^{*}$ & 11.5 & 13.6 & 12.5 & $0.0^{*}$ & 4.2 & 8.3 \\
\hline $\begin{array}{l}\text { Sever headache or } \\
\text { blurred vision }\end{array}$ & 23.3 & $14.5^{*}$ & 14.8 & 11.9 & 12.5 & $0.0^{*}$ & 4.2 & 8.3 \\
\hline $\begin{array}{l}\text { Baby moving less or } \\
\text { not moving at all }\end{array}$ & - & - & 26.2 & 20.3 & - & - & 33.3 & 37.5 \\
\hline Convulsions or fits & - & - & 3.3 & 3.4 & - & - & 0.0 & 0.0 \\
\hline Premature labour & - & - & & 13.6 & - & - & - & 0.0 \\
\hline $\begin{array}{l}\text { Discussed quantity of } \\
\text { food to eat }\end{array}$ & 58.1 & $66.7^{\text {** }}$ & 60.0 & $64.4^{* *}$ & 29.2 & $29.2^{* *}$ & 37.5 & $33.3^{* *}$ \\
\hline $\begin{array}{l}\text { Discussed personal } \\
\text { hygiene }\end{array}$ & 29.0 & 28.3 & 30.0 & 21.1 & 25.0 & 25.0 & 25.0 & 25.0 \\
\hline $\begin{array}{l}\text { Advice on rest and } \\
\text { exercise }\end{array}$ & 12.9 & 10.2 & 15.0 & 19.3 & 25.0 & 25.0 & 25.0 & 25.0 \\
\hline
\end{tabular}

${ }^{* *} \mathrm{p}<0.01 ; \quad \quad{ }^{*} \mathrm{p}<0.05 \quad-=$ Not Applicable 


\begin{tabular}{|c|c|c|c|c|c|c|c|c|}
\hline \multicolumn{9}{|c|}{$\begin{array}{c}\text { Table B5: Proportion of interactions where provider counseled clients on different } \\
\text { elements of birth planning, by visit and site }\end{array}$} \\
\hline Service Component & \multicolumn{4}{|c|}{ Intervention (\%) } & \multicolumn{4}{|c|}{ Comparison (\%) } \\
\hline $\begin{array}{l}\text { Elements of birth } \\
\text { planning }\end{array}$ & $\begin{array}{c}V_{1} \\
(N=62)\end{array}$ & $\begin{array}{c}\mathrm{V}_{2} \\
(\mathrm{~N}=62)\end{array}$ & $\begin{array}{c}\mathrm{V}_{3} \\
(\mathrm{~N}=61)\end{array}$ & $\begin{array}{c}\mathrm{V}_{4} \\
(\mathrm{~N}=60)\end{array}$ & $\begin{array}{c}\mathrm{V}_{1} \\
(\mathrm{~N}=24)\end{array}$ & $\begin{array}{c}\mathrm{V}_{2} \\
(\mathrm{~N}=24)\end{array}$ & $\begin{array}{c}\mathrm{V}_{3} \\
(\mathrm{~N}=24)\end{array}$ & $\begin{array}{c}\mathrm{V}_{4} \\
(\mathrm{~N}=24)\end{array}$ \\
\hline $\begin{array}{l}\text { Inform client on due date } \\
\text { for delivery }\end{array}$ & 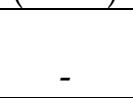 & 1 & 6.6 & & - & 1 & 12.5 & \\
\hline $\begin{array}{l}\text { Inform client about } \\
\text { progress of the } \\
\text { pregnancy }\end{array}$ & $61.3^{* *}$ & 59.7 & 60.7 & 50.8 & $37.5^{* *}$ & 54.2 & 50.0 & 54.2 \\
\hline $\begin{array}{l}\text { Ask client where she } \\
\text { plans to deliver }\end{array}$ & $21.0^{* *}$ & 8.2 & 8.2 & 11.9 & $0.0^{* *}$ & 0.0 & 0.0 & 8.3 \\
\hline $\begin{array}{l}\text { Advise the client to use a } \\
\text { skilled health worker } \\
\text { during delivery }\end{array}$ & 8.1 & 4.9 & 1.6 & 6.8 & 0.0 & 4.2 & 0.0 & 4.2 \\
\hline $\begin{array}{l}\text { Ask the client about who } \\
\text { else will provide support }\end{array}$ & 4.8 & 8.2 & 1.6 & 5.1 & 0.0 & 0.0 & 0.0 & 4.2 \\
\hline Discuss birth partners & 3.2 & 3.2 & 1.6 & 6.8 & 0.0 & 0.0 & 0.0 & 4.2 \\
\hline $\begin{array}{l}\text { Advice client to involve } \\
\text { the birth partner in } \\
\text { making the Individual } \\
\text { Birth Plan }\end{array}$ & 4.8 & 3.2 & 1.6 & 5.1 & 4.2 & 0.0 & 0.0 & 4.2 \\
\hline $\begin{array}{l}\text { Discuss the role to be } \\
\text { played by a birth partner }\end{array}$ & 0.0 & 0.0 & 1.6 & 3.4 & 0.0 & 0.0 & 0.0 & 0.0 \\
\hline $\begin{array}{l}\text { Advise client about } \\
\text { supplies to have on hand } \\
\text { at home }\end{array}$ & $40.3^{* *}$ & 17.7 & 19.7 & 28.8 & $70.8^{\star *}$ & 29.2 & 16.7 & 45.8 \\
\hline $\begin{array}{l}\text { Ask about who will care } \\
\text { for the family during } \\
\text { delivery }\end{array}$ & 0.0 & 1.6 & 1.6 & 0.0 & 0.0 & 0.0 & 0.0 & 0.0 \\
\hline $\begin{array}{l}\text { Ask client about which } \\
\text { health care facility to go } \\
\text { to in case of complication }\end{array}$ & 8.1 & 0.0 & 4.9 & 5.1 & 0.0 & 4.2 & 0.0 & 4.2 \\
\hline $\begin{array}{l}\text { Ask about her financial } \\
\text { arrangements }\end{array}$ & $4.8^{\star *}$ & 3.2 & 6.6 & 3.4 & $29.2^{\star *}$ & 0.0 & 0.0 & 4.2 \\
\hline $\begin{array}{l}\text { Advise on signs of } \\
\text { labour }\end{array}$ & - & - & 6.9 & 7.4 & - & - & 0.0 & 0.0 \\
\hline
\end{tabular}




\begin{tabular}{|c|c|c|c|c|}
\hline \multicolumn{5}{|c|}{$\begin{array}{c}\text { Table B6: Proportion of clients who received counseling on plans for postpartum care, by } \\
\text { visit and site }\end{array}$} \\
\hline \multirow[b]{2}{*}{ Service Component } & \multicolumn{2}{|c|}{ Intervention } & \multicolumn{2}{|c|}{ Comparison } \\
\hline & $\begin{array}{c}V_{3} \\
(\mathrm{~N}=61)\end{array}$ & $\begin{array}{c}\mathrm{V}_{4} \\
(\mathrm{~N}=60)\end{array}$ & $\begin{array}{c}\mathrm{V}_{3} \\
(\mathrm{~N}=24)\end{array}$ & $\begin{array}{c}V_{4} \\
(N=24)\end{array}$ \\
\hline Advise client on use of family planning after delivery & 13.1 & 3.4 & 0.0 & 0.0 \\
\hline Refer client to family planning clinic & 1.6 & 0.0 & 0.0 & 0.0 \\
\hline Advise client to visit post partum clinic & 1.7 & 0.0 & 0.0 & 0.0 \\
\hline $\begin{array}{l}\text { Advise client to visit well baby clinic for } \\
\text { immunization }\end{array}$ & 0.0 & 0.0 & 0.0 & 0.0 \\
\hline Discuss importance of immunization for new born & 0.0 & 0.0 & 0.0 & 0.0 \\
\hline Advise on care of breast and exclusive breast feeding & - & 8.5 & - & 8.5 \\
\hline
\end{tabular}

\begin{tabular}{|l|c|c|c|c|c|c|c|c|}
\hline \multicolumn{7}{|c|}{ Table B7: Proportion of client-provider interactions where continuity of care was ensured, } \\
by visit and site \\
\hline $\begin{array}{l}\text { Service } \\
\text { Component }\end{array}$ & $\begin{array}{c}\mathrm{V}_{1} \\
(\mathrm{~N}=62)\end{array}$ & $\begin{array}{c}\mathrm{V}_{2} \\
(\mathrm{~N}=62)\end{array}$ & $\begin{array}{c}\mathrm{V}_{3} \\
(\mathrm{~N}=61)\end{array}$ & $\begin{array}{c}\mathrm{V}_{4} \\
(\mathrm{~N}=60)\end{array}$ & $\begin{array}{c}\mathrm{V}_{1} \\
(\mathrm{~N}=24)\end{array}$ & $\begin{array}{c}\mathrm{V}_{2} \\
(\mathrm{~N}=24)\end{array}$ & $\begin{array}{c}\mathrm{V}_{3} \\
(\mathrm{~N}=24)\end{array}$ & $\begin{array}{c}\mathrm{V}_{4} \\
(\mathrm{~N}=24)\end{array}$ \\
\hline $\begin{array}{l}\text { Ensured privacy, } \\
\text { confidentiality }\end{array}$ & $100^{* *}$ & $100^{* *}$ & $100^{* *}$ & $98.3^{* *}$ & $75.0^{* *}$ & $75.0^{* *}$ & $75.0^{* *}$ & $75.0^{* *}$ \\
\hline $\begin{array}{l}\text { Client told what was } \\
\text { to be done }\end{array}$ & $74.2^{* *}$ & 74.2 & $75.4^{* *}$ & 68.3 & $33.3^{* *}$ & 58.3 & $50.0^{* *}$ & 50.0 \\
\hline $\begin{array}{l}\text { Looked at client } \\
\text { health card before } \\
\text { consultation }\end{array}$ & 100 & 100 & 100 & 100 & 100 & 95.8 & 100 & 100 \\
\hline $\begin{array}{l}\text { Ask client for any } \\
\text { concerns and } \\
\text { encourage questions }\end{array}$ & $95.2^{* *}$ & $100^{* *}$ & $95.1^{* *}$ & $93.3^{* *}$ & $62.5^{* *}$ & $75.0^{* *}$ & $50.0^{* *}$ & $66.7^{* *}$ \\
\hline Write on clients card & 95.2 & 98.4 & 100 & 98.3 & 100 & 100 & 100 & 100 \\
\hline $\begin{array}{l}\text { Inform clients about } \\
\text { due date }\end{array}$ & $6.6^{* *}$ & $4.8^{*}$ & 6.6 & $6.7^{* *}$ & $26.1^{* *}$ & $20.8^{*}$ & 12.5 & $29.2^{* *}$ \\
\hline $\begin{array}{l}\text { Give client the return } \\
\text { date }\end{array}$ & 93.4 & 100.0 & 98.4 & 100 & 95.8 & 95.8 & 100 & 100 \\
\hline
\end{tabular}

${ }^{* *} \mathrm{p}<0.01 ; \quad{ }^{*} \mathrm{p}<0.05$ 